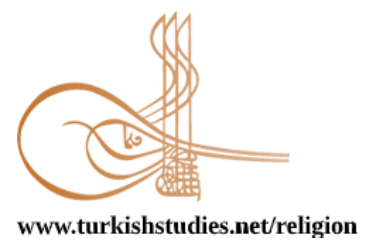

Turkish Studies - Comparative Religious Studies

eISSN: 2667-5544
Research Article / Araştırma Makalesi

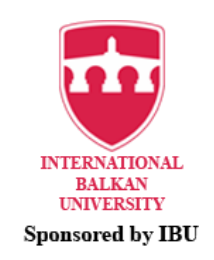

Sponsored by IBU

\title{
Özgüven ve Dindarlık İlişkisi: İlahiyat Öğrencileri Üzerine Bir Araştırma
}

\author{
Self-confidence and Religiosity Relationship: A Research on Students of Theology
}

\author{
Selahattin Yakut ${ }^{*}$
}

\begin{abstract}
Human beings are beings who come into the world full of emotional, mental and psychosocial potentials that can lead an ideal life in an individual sense. Although these potentials are revealed and functional, they are related to environmental factors and hereditary characteristics, but it is a matter that requires individual effort as the main factor. In this context, self-confidence and religiosity, which stand out as concepts that we can refer to as the reference to awareness of the potentials and the shaping of the psychological threshold in dealing with the problems faced; In addition to referring to human physical and psychological health, it can be considered as two of the most central determinants of quality of life. Considering the roles they play in shaping the psycho-social world of people, it makes our research important to examine the effects of self-confidence and religiosity on theology students in the pandemic process, which constantly increases its tone and severity in our country as in the whole world. The sample group of our study, which was confirmed to be in compliance with ethical rules by the decision of Bozok University Ethics Committee on 18.06.2020, with the decision numbered E-13509, was 108 (79.4\%) girls and 28 (20.6\%) boys, randomly selected through the communication tools of Yozgat Bozok University Faculty of Theology. It consists of a total of 136 students. The data were obtained using "personal data form", "selfconfidence scale" and "internal religious orientation scale" in our research, which adopted a descriptive model as a Model. Standard deviation, arithmetic mean and frequency analysis from descriptive statistics in SPSS program; the Man Whitney U test, Kruskal Wallis H Test, Spearman correlation and Post hoc analysis of non-parametric tests were performed with the acceptance of significance $p<0.05$ and the following results were achieved: "the participants had high levels of self-confidence and religiosity; the relationship between self-confidence and religiosity did not reach the level of significance.; the difference between the perception of personal piety and self-confidence and the economic situation on self-confidence is statistically significant, but gender, geographical region where the country is located, the duration of daily communication, daily personal development (reading books, courses, seminars, etc.). it was determined that the difference between the allotted time, the perception of the negative impact of the pandemic process on daily life, and the variables" shelter place " were not significant.
\end{abstract}

Structured Abstract: Man is a social and psychological entity, and as a reflection of this, very different arguments play a role in shaping the world of emotion, thought and behavior. Attaching a social and psychological meaning to every moment of your life is a common behavior for all people. But the factor that determines the level, limits, tone and severity of this behavior is the psychosocial structures of the people that show an individual difference. Man feels the effect of his inherited inherited traits in all his life. Again, one

*Dr. Öğr. Üyesi, Yozgat Bozok Üniversitesi İlahiyat Fakültesi, Felsefe ve Din Bilimleri Bölümü Asst. Prof. Dr. Yozgat Bozok University, Faculty of Theology, Department of Philosophy and Religious Sciences ORCID 0000-0002-3189-2123

selahattin.yakut@yobu.edu.tr

Cite as/ Atıf: Yakut, S. (2020). Özgüven ve dindarlık ilişkisi: ilahiyat öğrencileri üzerine bir araştırma. Turkish Studies - Religion, 15(3), 437-459. https://dx.doi.org/10.47091/TurkishStudies.45417

Received/Geliş: 20 July/Temmuz 2020

Accepted/Kabul: 20 September/Eylül 2020

Checked by plagiarism software

Copyright (C) INTAC LTD, Turkey

Published/Yayın: 25 September/Eylül 2020

CC BY-NC 4.0 
of the factors that it has felt in its life is the gains it gained from its very rich interactions in social life. Although it is not possible to express precisely which factor plays a role in shaping the social, cognitive, emotional, and intellectual structure of the human, it is possible to say that everything in his life has a different response in his psychosocial world. In this context, research stands out as the concepts of our subject, self-confidence and religiosity, both an expression of potentials and an indisputable psychosocial value in individuals' lives as a gain shaped by social interactions. Because self-confidence and religiosity have the potential to affect a person's life as emotion, thought and behavior. It is possible to show the traumatic processes as the time periods when the potentials of people are revealed and these potentials are almost tested. If traumatic processes have become a social and even global power, especially beyond individual boundaries, the potential of individuals becomes even more important and meaningful. In this context, the evolution of the pandemic process, called Covid-19, to an individual and socially threatening level all over the world, accelerates the pandemic's risk of many physiological and psychological disorders. Therefore, investigating the effects of the spiral of these problems on humans is of utmost importance. As it is not possible to foresee the limits of the impact of a psychosocial problem to be created by the pandemic process on the students of the Faculty of Theology, which we can position as teachers and religious official candidates, it should not be forgotten that this problem will also pose a risk for the fulfillment of educators and religious official missions in a healthy and appropriate manner. In this context, although our research is carried out only on the sample of theology students, the data of our study, which is a response to the pandemic process of the students of the Faculty of Theology, and the level of influence of this process on them, contributes both to the literature related to the pandemic process and to the literature regarding the areas of self-confidence and religiosity.

Research; As one of the concepts associated with self-confidence and self-confidence, it aims to analyze and understand the effects of religiousness on the students of the Faculty of Theology in terms of various variables. The sample group of the research; It consists of 108 (79.4\%) girls and 28 (20.6\%) boys in total, selected from the Yozgat Bozok University Faculty of Theology via communication tools. The data were obtained using "personal data form", "self-confidence scale" and "internal religious orientation scale" in our research, which adopted a descriptive model as a Model. Man Whitney U test, Kruskal Wallis H Test, Spearman correlation and Post hoc analysis operations from non-parametric tests were applied in SPSS program and the following results were obtained by accepting significance $p<0.05$ :

1. The general self-confidence and religiosity levels of the participants are high.

2. There was no significant relationship between self-confidence and religiousness.

3. The difference created by the perception of personal religiosity over self-reliance and religiousness is statistically significant.

4. Those with high economic status have high self-esteem and the difference is statistically significant. However, the difference created by the economic situation on piety was not significant.

5- Gender, geographical region where the hometown is located, daily occupation time by means of communication, daily development for personal development (reading books, courses, seminars, etc.), perception regarding the negative impact of the pandemic process on daily life, the difference created by the accommodation variables were not statistically significant.

In our study, the following suggestions were made in the context of the meaningful difference of personal religiosity perception on self-confidence and religiosity:

In our study, the following suggestions were made in the context of self-reliance of the high economic situation and the meaningful difference of personal religiousness perception on self-confidence and religiosity:

1. Religious education should be carried out with a curriculum that will contribute to the development of the emotional, thought, social and psychological aspects of the person, supported by scientific methods on a non-dogmatic, questioning mental infrastructure.

2. The necessary educational infrastructure should be prepared for the formation of a healthy understanding of religiosity, which shows the smiling face of religion, prioritizes human relations, is free from radicalism, is not alienating but unifying. 
3. Considering the potential of self-perception to affect students' psychosocial structures, the activities that develop self-perception should be given importance.

4. Students should be supported economically to cover all kinds of needs related to educational processes such as housing, clothing, transportation, and educational materials.

Keywords: Religious psychology, Self Confidence, Religion, Religiosity, Pandemic

Öz: İnsan, bireysel anlamda hayatını en ideal şekilde devam ettirebilecek duygusal, zihinsel ve psiko-sosyal potansiyellerle dünyaya gelen bir varlıktır. Bu potansiyellerin açığa çıkması ve işlevsel hale gelmesi, çevresel faktörler ve kalıtımsal özelliklerle ilişkili olmakla birlikte en temel etken olarak bireysel çabayı gerekli kılan bir husustur. $\mathrm{Bu}$ bağlamda potansiyellerin farkındalığına ve yüzleşilen problemlerle baş etmede psikolojik eşiğin şekillenmesine referans olarak gösterebileceğimiz kavramlar olarak ön plana çıkan özgüven ve dindarlık; insanın bedensel ve psikolojik sağlığına atıfta bulunmalarının yanında hayat kalitesinin de en merkezi belirleyicilerinden ikisi olarak değerlendirilebilir. Özellikle insanın psiko-sosyal dünyasının şekillenmesinde üstlendikleri roller düşünüldüğünde özgüven ve dindarlığın, tüm dünyada olduğu gibi ülkemizde de tonunu ve şiddetini sürekli artıran pandemi sürecinde ilahiyat öğrencileri üzerindeki etkilerini çeşitli faktörler açısından inceleme amaçlı araştırmamızı önemli kılmaktadır. Bozok Üniversitesi Etik Kurulu'nun 18.06.2020 tarihli toplantısında E-13509 sayılı kararıyla etik kurallara uygun olduğu teyit edilen araştırmamızın örneklem grubu Yozgat Bozok Üniversitesi İlahiyat Fakültesi’nin iletişim araçları aracılığıyla seçkisiz olarak seçilen 108 (\% 79.4) kız ve 28 (\% 20.6) erkek olmak üzere toplam 136 öğrencisinden oluşmaktadır. Model olarak betimsel model benimsenen araştırmamızda veriler "Kișisel Bilgi Formu", "Özgüven Ölçeği”" ve "İçsel Dini Yönelim Ölçeği” kullanılarak elde edilmiştir. SPSS programında tanımlayıcı istatistiklerden standart sapma, aritmetik ortalama ve frekans analizi; verilerin normal dağılım şartlarını tam olarak sağlayamaması üzerine non parametrik testlerden Man Whitney U Testi, Kruskal Wallis H Testi, Spearman korelasyon ve Post hoc analiz işlemleri anlamllık $\mathrm{p}<0.05$ kabul edilerek uygulanmış ve şu sonuçlara ulaşılmıştır: "Katılımcıların özgüven ve dindarlık düzeylerinin yüksek olduğu; özgüven ile dindarlık arasında tespit edilen ilişkinin anlamlılık düzeyine ulaşmadığı; kişisel dindarlık algısının özgüven ve dindarlık üzerinde oluşturduğu fark ile ekonomik durumun özgüven üzerinde oluşturduğu farkın istatistiksek açıdan anlamlı olduğu ancak cinsiyet, memleketin bulunduğu coğrafi bölge, günlük iletişim araçlarıyla meşguliyet süresi, günlük kişisel gelişime (kitap okuma, kurs, seminer vb. etkinlikler) ayrılan süre, pandemi sürecinin günlük hayata olumsuz etkisine yönelik alg1, barınma yeri" değişkenlerinin oluş̧urduğu farkın ise anlamlı olmadığı tespit edilmiş̧ir.

Anahtar Kelimeler: Din Psikolojisi, Özgüven, Din, Dindarlık, Pandemi

\section{Giriş}

İnsan, kalıtımsal potansiyellerini yaşam sürecindeki etkileşimlerinin bir sonucu işlevsel hale getiren ve potansiyellerini geliştirdiği gibi bu süreçte yeni potansiyeller de edinen bir varlıktır. İnsanın hayat serüveninde pasif değil aktif rol oynayabilmesi ve nesne olmak yerine özne olarak hayat şartlarını belirlemede etkin olabilmesi, bu süreçteki kazanımları ölçüsünde gerçekleştirebileceği bir husustur. Bu bağlamda özgüven; insanın gelişim süreci içerisinde edindiği kazanımlarının bireysel ve sosyal yaşantısında somutlaşan performan ve psiko-sosyal kapasitenin de bir dışavurumu şeklinde sembolize edebileceğimiz bir kavram olarak ön plana çıkmaktadır. İnsanın psikolojik ve duygusal dünyasının en belirgin bileşenlerinden birisi olarak kabul gören özgüven (Mckay ve Fanning, 2016), eksikliği durumunda hayatın her aşamasında farklı sorunlara kaynaklık edebilecek potansiyele sahip (Noyan Yalman ve Özkaynar, 2018) ve dolayısıyla mutluluk için referans teşkil eden (Aydıner, 2011) duygusal yönlü bir kapasite olarak anlamlandırılabilir.

Kendimizle ilgili değerlilik algısı (Bandura, 1997), tüm yönlerimizi kapsayan kendilik algımızla tutum ve davranışlarımızı yönlendirme irademiz (Lauster, 2000), yüzleşilen sorunların üstesinden gelebilme becerisi (Koç ve Gün, 2007), içsel dünyada sağlanan bütünlük sonucu kendimizle ve çevremizle barışık olabilme düzeyi (Akagündüz, 2006), yeteneklerin farkındalığıyla 
birlikte cesaret gösterebilme (Karademir,2015) olarak tanımlanan özgüven, kişiliğin (Bilgin, 2017) ve davranışların en temel belirleyicilerinden birisi olarak (Eldeleklioğlu, 2004) değerlendirilmekte ve bu yönüyle onun insanın yaşamı boyunca tüm iletişim ve etkileşim süreçlerine atıfta bulunan bir anlam derinliğine sahip olduğu düşünülmektedir.

Yapılan araştırmalarda özgüvenin; konuşma becerisi (Gürler, 2015), benlik saygıs1 (Gündoğdu, 2019), yaşam amacı (Bilgin, 2017), öz-yeterlik ve sosyal beceri (Alphan, 2018), affedicilik (Aslan, 2016), duygusal zeka (Çetin,2019), kriz yönetimi ve karar verme becerisi (Atılgan,2018), sosyal beceri (Soykan ve Mirzeoğlu, 2020), psikolojik dayanıklılık (Akkuş, 2015), stresle başa çıkma (Mandıralı, 2019), psikolojik sağlamlık (Elsel, 2019), empati (Aka, 2019), yaşam doyumu ve yaşam kalitesi (Altuntaş, 2019), aile uyumu (soner, 1995), liderlik (Erpalabiyık, 2018) gibi olumlu özelliklerle tespit edilen pozitif yönlü ilişkisi; anksiyete (Merey, 2010; Parçal, 2018), kayg1 (Toktaş, 2017), stres (Kırman, 2013), olumsuz otomatik düşünceler (yalnızlık, ümitsizlik, uyumsuzluk, izolasyon) (Çalıkuşu, 2020), internet bağımlılığı (Erden, 2019), şiddet (Sarkın, 2012; Dursun, 2018), korku (Bostancı vd., 2018) gibi olumsuz duygu durumlarıyla tespit edilen negatif yönlü ilişkisi, özgüvenin psikolojik sağlığa referans teşkil eden hususları desteklediğini ve insanın psikolojik, sosyal ve mental sağlı̆̆ 1 açısından merkezi bir rol oynadığını bizlere göstermektedir.

Buna ilaveten pozitif duyguların beden ve ruh sağlı̆̆ıyla; negatif duyguların psikolojik ve fizyolojik hastalıklarla ilişkisi (Campos vd., 1989) bağlamında özgüvenin pozitif duyguların gelişiminde önemli bir motivasyon unsuru olduğunu varsaymak ve bir bütün olarak her yönüyle bireyin sağlığı açısından son derece önemli bir referans kaynağı olduğunu dile getirmek mümkündür. Özellikle özgüven düzeyi düşük bireylerin özgüveni yüksek bireylere oranla stres, kaygı ve değersizlik hissini yoğun olarak yaşamaları, kendi kararlarını veremeyen bağımlı bir kişilik geliştirmeleri (Altıntaş, 2015) baskın bir yetersizlik ve buna bağlı gelişen cesaretsizlik duygusuna sahip olmaları (Kasatura, 1998) bu değerlendirmeyi destekler niteliktedir.

Özgüven ile insanın duygu, düşünce, davranış ve psiko-sosyal dünyasının şekillenmesinde etkili kavramlardan birisi olarak değerlendirilen dindarlığı (Tokur, 2014) ilişkilendirmenin mümkün olup olmadığı sosyal bilimlerin en temel amaçlarından insanın anlaşılmasına gönderme niteliğindedir. Zira insanın hayatına yön vermede benimsediği düşünce, inanç, ilke ve değerler bütünü olarak tanımlanan dinin (Demir ve Acar, 1997) bireysel ve toplumsal hayatta somutlaşması olarak anlamlandırabileceğimiz dindarlığın (Günay, 2006) özgüvenle de ilişkilendirilen benlik saygısı (Ekmekçi, 2016), depresyon (Cengil, 2003), kaygı (Şeftalici, 2017), stresle başa çıkma (Tokur, 2011), psikolojik sağlamlık (Türker, 2018), empati Çakır, 2015), yaşam doyumu (Yazıcı, 2018), yaşam kalitesi (Acat, 2019), aile uyumu (Geçioğlu, 2018) gibi duygusal yoğunluklu konularla ilişkilendirilmesi, özgüven ve dindarlık ilişkisine referans olmanın yanında, insanın psiko-sosyal dünyasının şekillenmesinde birlikte üstlendikleri rollerine de bir vurgu niteliğindedir. Yine bedensel ve psikolojik sağlığa atıf niteliği taşıyan öznel iyi oluş (Gencer, 2019a), mutluluk (Gezenler, 2019; Aydemir, 2008), psikolojik dayanıklılık (İnce, 2019), psikolojik sağlık (Çalışır, 2014), psikolojik iyi oluş (Tura, 2019), psikolojik sağlamlık (Sezgin, 2016), hayatı anlamlandırma (İnan, 2019), ruh sağlı̆̆ (Şengül, 2007) gibi psiko-sosyal değerlerle dindarlık arasında tespit edilen ilişki, dindarlığın bedensel ve psikolojik sağlık açısından önemsenmesi gereken bir olgu olduğunun en somut göstergelerindendir. Tüm bu bilgiler özgüven ve dindarlığın insan açısından önemini vurgulamaktadır.

Dindarlığın insan üzerinde öngörülen pozitif etkisi, sağlıklı bir dindarlık algısıyla şekillenebilecek bir husustur. İnsanın duygu ve düşünce dünyasına pozitif dokunuşlar yapamayan, zihinsel sorulara tatmin edici cevaplar bulamamanın oluşturduğu zihinsel kırılganlıklarla örülü, mutluluğuna katkı sağlayabilecek içerikten yoksun sığ bir dindarlık algısının çok farklı psikososyal problemlere kaynaklık etmesi, fizyolojik ve de ruhsal rahatsızlıkları tetiklemesi büyük bir olasılık olarak karşımızda durmaktadır. Sağlıklı bir dindarlığın yine bilimsel yöntemlerle 
desteklenen sağlkklı bir din eğitimiyle inşâ edilebileceği tartışmasız bir gerçekliktir. Bu bağlamda din eğitiminin kalitesiyle ilişkilendirilebilecek hususlardan birisi hiç şüphesiz din eğitimcisi adayları olarak İlahiyat fakültesi öğrencilerinin eğitim süreçlerinin kalitesi yanında sahip oldukları psiko-sosyal kapasiteleridir. Özgüven ve dindarlı̆̆ın, insanın çok boyutlu yapısı üzerinde en temel belirleyicilerden olduğu ön kabulümüzden hareketle, bu iki olgunun ilahiyat öğrencileri üzerindeki etkilerinin araştırılması son derece önem arz etmektedir. Zira ilahiyat öğrencilerinin özgüven ve dindarlık özelinde yaşamaları muhtemel bir problemin onlar üzerinde daha farklı psikososyal problemlere neden olabileceği ve hatta ileride üstlenecekleri eğitimin en önemli ögelerinden olma misyonlarını da yerine getirmede sıkıntı yaşayabilecekleri öngörülebilir bir durumdur.

Ayrıca çalışmamızı önemli kılan diğer bir husus; tüm dünyada olduğu gibi ülkemizde de bireysel ve toplumsal hayatta olumsuz yansımaları şiddetini artırarak devam eden ve Dünya Sağlık Örgütü tarafından pandemi (küresel salgın) olarak kabul edilen Covid-19 (WHO,2020) adı verilen salgın sürecinin ilahiyat öğrencileri üzerindeki etki potansiyelinin incelenmesine katkı niteliğinde olmasıdır. Bu süreçte iletişim araçlarında salgının yol açtığı ölümlerin yoğun olarak işlenmesi, bu durumun hastalanma korkusunun daha yoğun yaşanmasına yol açması, karantina uygulamalarının oluşturduğu monoton bir hayat ve bu hayata bağl1 olarak geliştiğini öngördüğümüz stres ve depresyon, önceden tecrübe edilmemiş bir eğitim süreci, iş ve çalışma koşullarında yaşanan aksaklıklara bağlı olarak ailelerin yaşadığı ekonomik sıkıntı ve bunun tüm aile bireylerine olumsuz yansımaları gibi benzer problemler, salgın sürecinin etkilerinin bireysel ve toplumsal bazda daha baskın olarak hissedilmesine neden olmaktadır. Bununla birlikte bu sürecin oluşturduğu tüm bu olumsuz atmosfer, pandeminin fizyolojik ve psikososyal rahatsızlıkları tahminlerin üzerinde bir boyutta tetikleyebilecek bir yapıya evrilmesi riskini de artırmıştır. Araştırmamızın sadece İlahiyat öğrencileri örneklemi üzerinde yapılması bir sınırlılık olarak kabul edilebilir ancak yine de pandemi süreci içerisinde yapılan araştırmamızın sonuçlarının hem özgüven ve dindarlığın ilahiyat öğrencileri üzerindeki etkilerini anlama hem de pandemi sürecinin etkilerinin boyutlarını anlamlandırma açısından önemli katkılar sunması beklenmektedir.

\section{Araştırmanın Amacı:}

Sağlıklı bir din ve dindarlık anlayışının teşekkülü için önemli görülen İlahiyat Fakültesi öğrencilerinin özgüven ve dindarlık düzeylerini çeşitli değişkenler açısından inceleme amacı taşıyan araştırmamızda şu sorulara cevap aranmıştır:

1- Özgüven ve dindarlık cinsiyete göre değişmekte midir?

2- Özgüven ve dindarlık ekonomik duruma göre değişmekte midir?

3- Özgüven ve dindarlık memleketin bulunduğu coğrafi bölgeye göre değişmekte midir? midir?

4- Özgüven ve dindarlık iletişim araçlarıyla günlük meşguliyet süresine göre değişmekte

5- Özgüven ve dindarlık kişisel gelişime (kitap okuma, kurs, seminer vb. etkinlikler) günlük ayrılan süreye göre değişmekte midir?

6- Özgüven ve dindarlık kişisel dindarlık algısına göre değişmekte midir?

7- Özgüven ve dindarlık pandemi sürecinin günlük hayata olumsuz etkisine yönelik algıya göre değişmekte midir?

8- Özgüven ve dindarlık, üniversite eğitiminde barınma yerine göre değişmekte midir?

9- Özgüven ve dindarlık arasındaki ilişki anlamlı mıdır?

10- Örneklemin genel olarak özgüven ve genel dindarlık düzeyi nedir? 


\section{Yöntem}

Yozgat Bozok Üniversitesi İlahiyat Fakültesi'nin iletişim araçları aracılı̆̆ıyla seçkisiz olarak seçilen öğrencilerinin özgüven ve dindarlık düzeylerini cinsiyet, ekonomik durum, memleketin bulunduğu coğrafi bölge, iletişim araçlarıyla günlük meşguliyet süresi, kişisel gelişime (kitap okuma, kurs, seminer vb. etkinlikler) günlük ayrılan süre, kişisel dindarlık algısı, pandemi sürecinin günlük hayata olumsuz etkisine yönelik alg1, barınma yeri değişkenlerine göre sınama amacı taşıyan ve Bozok Üniversitesi Etik Kurulu'nun 18.06.2020 tarihli toplantısında E-13509 sayılı kararıyla etik kurallara uygun olduğu teyit edilen araştırmamızda betimsel (survey) model benimsenmiştir. Örneklemin seçkisizliği, evreni temsil etmede yöntemin güçlülüğünü ve diğer yöntemlerden temsil olasılığının yüksekliğini göstermektedir (Karasar, 2009).

\section{Araştırma Grubunun Özellikleri:}

136 kişiden oluşan ve seçkisiz olarak seçilen örneklemin yüzdelik dağılımları şu şekildedir:

Tablo 1: Cinsiyete Göre Dağılım

\begin{tabular}{|c|c|c|}
\hline Cinsiyet & f & $\%$ \\
\hline Kiz & 108 & 79.4 \\
\hline Erkek & 28 & 20.6 \\
\hline Toplam & 136 & 100.0 \\
\hline
\end{tabular}

Cinsiyet değişkenine göre kızların katılım oranının daha yüksek olduğu görülmektedir.

Tablo 2: Ailenin Ekonomik Durum Düzeyine Göre Dağılım

\begin{tabular}{|c|c|c|}
\hline Ailenin Ekonomik durumu & f & $\%$ \\
\hline Düşük & 7 & 5.1 \\
\hline Orta düzey & 104 & 76.5 \\
\hline Yüksek & 25 & 18.4 \\
\hline Toplam & 136 & 100.0 \\
\hline
\end{tabular}

Ekonomik durum değişkenine göre orta düzey gelire sahip ailelere mensup olan katılımcıların oranının daha fazla olduğu görülmektedir.

Tablo 3: Memleketin bulunduğu Coğrafi Bölgeye Göre Dağılım

\begin{tabular}{|c|c|c|}
\hline Coğrafi Bölge & $\mathrm{f}$ & $\%$ \\
\hline Doğu Anadolu & 7 & 5.1 \\
\hline İç Anadolu & 96 & 70.6 \\
\hline Karadeniz & 9 & 6.6 \\
\hline Akdeniz & 13 & 9.6 \\
\hline Ege & 2 & 1.5 \\
\hline Marmara & 2 & 1.5 \\
\hline Güneydoğu Anadolu & 7 & 5.1 \\
\hline Total & 136 & 100,0 \\
\hline
\end{tabular}

Coğrafi bölge değişkenine göre en fazla katılımın İç Anadolu Bölgesi'nden en az katılımın ise Ege ve Marmara Bölgesi'nden olduğu görülmektedir.

Tablo 4: İletişim Araçlarıyla Günlük Meşguliyet Durumuna Göre Dağılım

\begin{tabular}{|c|c|c|}
\hline Meşguliyet Süresi & f & $\%$ \\
\hline 1 saat & 5 & 3.7 \\
\hline 2 saat & 33 & 24.3 \\
\hline 3 saat & 41 & 30.1 \\
\hline 4 saat & 34 & 25.0 \\
\hline 5 saat ve üzeri & 23 & 16.9 \\
\hline Total & 136 & 100.0 \\
\hline
\end{tabular}


Tablo 4'e göre iletişim araçlarıyla günlük meşguliyeti 3-4 saat olarak ifade eden katılımcıların oranının daha fazla olduğu görülmektedir.

Tablo 5: Günlük Kişisel Gelişime Ayrılan Süre Durumuna Göre Dağılım

\begin{tabular}{|c|c|c|}
\hline Meşguliyet Süresi & f & $\%$ \\
\hline 1 saat & 55 & 40.4 \\
\hline 2 saat & 37 & 27.2 \\
\hline 3 saat & 27 & 19.9 \\
\hline 4 saat & 9 & 6.6 \\
\hline 5 saat ve üzeri & 8 & 5.9 \\
\hline Total & 136 & 100.0 \\
\hline
\end{tabular}

Tablo 5'e göre en fazla oranın günlük kişisel gelişimine 1 saat ayıran katılımcılara ait olduğu; ayrılan sürenin arttıkça katılımcı oranının azaldığı görülmektedir.

Tablo 6: Kişisel Dindarlık Algısı Durumuna Göre Dağılım

\begin{tabular}{|c|c|c|}
\hline Dindarlık algısı & f & $\%$ \\
\hline Hiç dindar değilim & - & - \\
\hline Düşük düzey & 3 & 2.2 \\
\hline Orta düzey & 59 & 43.4 \\
\hline Dindarım & 64 & 47.1 \\
\hline Çok dindarım & 10 & 7.4 \\
\hline Total & 136 & 100.0 \\
\hline
\end{tabular}

Tablo 6’ya göre katılımcılardan "hiç dindar değilim” seçeneğini işaretleyenin bulunmadığı ve kendisini "dindarım" olarak ifade eden katılımcıların oranının daha yüksek olduğu görülmektedir.

Tablo7: Pandeminin Günlük Hayata Olumsuz Etkisini Puanlama Durumuna Göre Dağılım

\begin{tabular}{|c|c|c|}
\hline Pandeminin Olumsuz Etkisi & $\mathrm{f}$ & $\%$ \\
\hline 1 puan & 10 & 7.4 \\
\hline 2 puan & 16 & 11.8 \\
\hline 3 puan & 42 & 30.9 \\
\hline 4 puan & 32 & 23.5 \\
\hline 5 puan & 36 & 26.5 \\
\hline Total & 136 & 100.0 \\
\hline
\end{tabular}

Tablo 7'ye göre katılımcıların pandemi sürecinin olumsuz etkilerinden en fazla orta düzeyde etkilendikleri görülmektedir.

Tablo 8: Barınma Yerine Göre Dağ 11 mm

\begin{tabular}{|c|c|c|}
\hline Barınma Yeri & $\mathrm{f}$ & $\%$ \\
\hline Aile & 18 & 13.2 \\
\hline Özel yurt/pansiyon & 14 & 10.3 \\
\hline Devlet yurdu/pansiyon & 91 & 66.9 \\
\hline Kiralık daire & 13 & 9.6 \\
\hline Total & 136 & 100.0 \\
\hline
\end{tabular}

Katılımcıların büyük çoğunluğunun devlet yurdu veya devlet pansiyonunda barındıkları görülmektedir.

\section{Veri Toplama Araçları}

Araştırma veri toplama araçları olarak "Kişisel Bilgi Formu", "Özgüven Ölçeği" ve "Dindarlık Ölçeği” kullanılmıştır.

1.Kişisel Bilgi Formu: 
$\mathrm{Bu}$ form kullanılarak katılımcıların demografik özellikleri "cinsiyet, ekonomik durum, memleketin bulunduğu bölge, günlük iletişim araçlarıyla meşguliyet süresi, günlük kişisel gelişime (kitap okuma, kurs, seminer vb. etkinlikler) ayrılan süre, kişisel dindarlık algısı, pandemi sürecinin günlük hayata olumsuz etkisine yönelik algı, barınma yeri” ile ilgili bilgiler toplanmıştır.

\section{2. Özgüven Ölçeği:}

Psikoloji ve eğitim öncelikli olmak üzere özgüvenle ilişkilendirilebilecek tüm alanlarda bireylerin özgüven düzeyini tespi etmek için kullanılan ve madde sayısı otuzüç olan ölçek Akın (2007) tarafından geliştirilmiştir. Bireylerin içsel dünyalarında ve sosyal hayatta özgüveni ifade eden maddelere yer veren ölçek likert tipinde olup " hiç bir zaman, nadiren, sık sık, genellikle, her zaman" şeklinde 1-5 aralığında puanlanmaktadır. En yüksek puanı 165, en düşük puanı 33 olan ölçekten alınan yüksek puan özgüvenin yüksekliğini göstermektedir. Tüm maddeleri olumlu olan ölçeğin bütünü için iç tutarlılık katsayısı 0.83; Cronbach alfa değeri ise 0.94'tür (Akın,2007). Ölçeğin güvenilirliğine yönelik tarafımızca yapılan ölçümde ise Cronbach Alpha güvenirlik katsayısı da .85 olarak bulunmuştur. Bu katsayı değeri " 0 - 40 : güvenilir değil 40 - 60 : düşük güvenilirlik, 60 - 80 : oldukça güvenilir, 80 - 100 : yüksek derecede güvenilir" (Özdamar, 2002) aralığına göre yüksek derecede güvenilir olduğunu göstermektedir. Tüm bu değerler özgüven ölçeğinin geçerli ve güvenilir bir ölçme aracı olduğunu göstermektedir.

\section{3.İçsel Dini Yönelim Ölçeği:}

Katılımcıların dindarlık düzeylerini tespit etmek amacıyla Hoge (1972) tarafından geliştirilen ve Karaca (2000 / 2001) tarafindan Türkçe'ye uyarlanarak geçerlik ve güvenirlik analizleri yapılan içsel dini yönelim ölçeği kullanılmıştır. Son üç maddesi olumsuz sorulardan oluşan ve ters hesaplanan toplam 10 maddeli ölçeğin iç tutarlılık katsayıs1 .85, güvenirlik katsayıs1 .76 olarak tespit edilmiştir. Beşli likert tipi ölçekten en fazla 50, en düşük 10 puan alınmaktadır. Ölçeğin güvenirliğine yönelik tarafımızca testte Cronbach's alpha katsayısı .78 olarak bulunmuştur ve bu değer ölçeğin oldukça güvenilir olduğunu gösteren bir değerdir (Özdamar, 2002).

\section{İstatistiksel Analiz:}

Verilerin analizinde SPSS 22.0 programın kullanılmıştır. Verilerin normal dağılım şartlarını tam olarak sağlayamaması $(\mathrm{P}<0.05)$ nedeniyle nonparametrik testlerden Man Whitney $\mathrm{U}$ Testi, Kruskal Wallis H Testi ve Spearman korelasyon ve Post hoc analiz işlemleri anlamlılık p $<0.05$ kabul edilerek uygulanmıştır. Ek olarak standart sapma, aritmetik ortalama ve frekans analizi de tanımlayıcı istatistikler olarak kullanılmıştır.

\section{Bulgular}

Bölümde katılımcılara uygulanan "Özgüven" ve "Dindarlık" ölçeklerinden elde edilen verilerle ilgili istatistiksel işlemlere ve bu işlemler sonucu tespit edilen bulgularla ilgili yorumlara yer verilmiştir. şeklindedir.

1. Araştırmanın birinci sorusu "Özgüven ve dindarlık cinsiyete göre değişmekte midir?"

Tablo 9: Cinsiyet Değiş̧kenine Göre Dindarlık ve Özgüven Puanları için Man Whitney U Testi Sonuçları

\begin{tabular}{|c|l|c|c|c|c|c|c|c|}
\hline Ölçek & Cinsiyet & $\mathrm{N}$ & Ort. & SS & Sıra Ort. & $\begin{array}{c}\text { Sıra } \\
\text { Top. }\end{array}$ & U & P \\
\hline \multirow{2}{*}{ Dindarlık } & Kız & 108 & 4.33 & 0.412 & 67.62 & 7303.00 & \multirow{2}{*}{1417.000} & \multirow{2}{*}{0.608} \\
\cline { 2 - 7 } & Erkek & 28 & 4.38 & 0.404 & 71.89 & 2013.00 & & \\
\hline \multirow{2}{*}{ Özgüven } & Kız & 108 & 3.85 & 0.463 & 69.27 & 7481.50 & \multirow{2}{*}{1428.500} & \multirow{2}{*}{0.653} \\
\cline { 2 - 7 } & Erkek & 28 & 3.75 & 0.574 & 65.52 & 1834.50 & 1428 \\
\hline
\end{tabular}


Tablo 9'a baktığımızda erkek katılımcıların dindarlık puanlarının kızlardan yüksek olduğu $(X=4.38)$; kızlarrın özgüven puanlarının ise erkeklerden yüksek olduğu $(X=3.85)$ ancak hem dindarlık $(U=1417.0000 ; p=0.608 ; p>0.05)$ hem de özgüven üzerinde $(U=1428.500 ; p=0.653$; p>0.05) cinsiyet değişkeninin oluşturduğu farkın anlamlılık düzeyine ulaşmadığı görülmektedir.

Araştırmanın ikinci sorusu "Özgüven ve dindarlık ekonomik duruma göre değişmekte midir?" şeklindeydi

Tablo 10: Ailenin Ekonomik Durumu Değişkenine Göre Dindarlık ve Özgüven Puanları Arasındaki Kruskal Wallis H Testi Sonuçları

\begin{tabular}{|c|c|c|c|c|c|c|c|c|}
\hline Ölçek & $\begin{array}{c}\text { Ailenin } \\
\text { ekonomik } \\
\text { durumu }\end{array}$ & $\mathrm{N}$ & Ort. & SS & Sira Ort. & $\mathbf{x}^{2}$ & $\mathrm{P}$ & Fark \\
\hline \multirow{3}{*}{ Dindarlık } & Düşük & 7 & 4.28 & .219 & 59.64 & \multirow{3}{*}{2.370} & \multirow{3}{*}{0.306} & \\
\hline & Orta & 104 & 4.31 & .422 & 66.59 & & & \\
\hline & Yüksek & 25 & 4.46 & .385 & 78.94 & & & \\
\hline \multirow{3}{*}{ Özgüven } & Düşük & 7 & 3.72 & .396 & 51.36 & \multirow[b]{3}{*}{4.267} & \multirow[b]{3}{*}{0.042} & $3>2$ \\
\hline & Orta & 104 & 3.79 & .489 & 66.09 & & & $3>2$ \\
\hline & Yüksek & 25 & 4.05 & .468 & 83.34 & & & \\
\hline
\end{tabular}

Tablo 10'a baktığımızda ekonomik durum değişkenine göre ekonomik durumunu "yüksek" olarak ifade eden katılımcıların hem dindarlık puanlarının $(X=4,46)$ hem de özgüven puanlarının $(X=4.05)$ diğer katılımcılardan yüksek olduğu ve ekonomik düzeyin artmasına bağlı olarak dindarlık ve özgüvenin de arttığ ancak oluşan farkın dindarlıkta $\left(\mathbf{x}^{2}=2.370 ; \mathrm{P}=0.306 ; \mathrm{P}>0.05\right)$ anlamlılık düzeyine ulaşmadığ ulaştığı görülmektedir.

Araştırmanın üçüncü sorusu "Özgüven ve dindarlık memleketin bulunduğu bölgeye göre değişmekte midir?" şeklindeydi.

Tablo 11: Memleketin Bulunduğu Coğrafi Bölge Değişkenine Göre Dindarlık ve Özgüven Puanları Arasındaki Kruskal Wallis H Testi Sonuçları

\begin{tabular}{|c|c|c|c|c|c|c|c|}
\hline Ölçek & Coğrafi Bölge & $\mathrm{N}$ & Ort. & SS & Sira Ort. & $\mathrm{x}^{2}$ & $\mathrm{P}$ \\
\hline \multirow{7}{*}{ Dindarlık } & Doğu Anadolu & 7 & 3.77 & .551 & 84.86 & \multirow[b]{7}{*}{3.774} & \multirow[b]{7}{*}{0.707} \\
\hline & İç Anadolu & 96 & 3.79 & .481 & 66.59 & & \\
\hline & Karadeniz & 9 & 3.76 & .519 & 72.28 & & \\
\hline & Akdeniz & 13 & 3.95 & .561 & 63.19 & & \\
\hline & Ege & 2 & 4.24 & .000 & 102.25 & & \\
\hline & Marmara & 2 & 4.28 & .192 & 88.75 & & \\
\hline & Güneydoğu Anadolu & 7 & 4.00 & .373 & 67.93 & & \\
\hline \multirow{7}{*}{ Özgüven } & Doğu Anadolu & 7 & 4.51 & .260 & 63.50 & \multirow{7}{*}{8.665} & \multirow{7}{*}{0.193} \\
\hline & İç Anadolu & 96 & 4.32 & .416 & 65.22 & & \\
\hline & Karadeniz & 9 & 4.38 & .301 & 58.39 & & \\
\hline & Akdeniz & 13 & 4.30 & .370 & 81.08 & & \\
\hline & Ege & 2 & 4.65 & .212 & 114.00 & & \\
\hline & Marmara & 2 & 4.55 & .353 & 111.25 & & \\
\hline & Güneydoğu Anadolu & 7 & 4.28 & .669 & 82.93 & & \\
\hline
\end{tabular}

Tablo 11'e baktığımızda memleketin bulunduğu coğrafi bölge değişkenine göre en yüksek dindarlık puanına Marmara Bölgesi katılımcılarının $(X=4.28)$; en yüksek özgüven puanına ise Ege Bölgesi katılımcılarının $(X=4.65)$ sahip olduğu görülmektedir. Fakat coğrafi bölge değişkeninin hem dindarlık üzerinde oluşturduğu fark $\left(\mathbf{x}^{2}=3.774 ; \mathrm{P}=0.707 ; \mathrm{P}>0.05\right)$ hem de özgüven üzerinde oluşturduğu fark $\left(\mathbf{x}^{2}=8.665 ; \mathrm{P}=0.193 ; \mathrm{P}>0.05\right)$ istatistiksel açıdan anlamlı bulunmamıştır. 
Araştırmanın dördüncü sorusu "Özgüven ve dindarlık günlük iletişim araçlarıyla meşguliyet süresine göre değişmekte midir?" şeklindeydi.

Tablo 12: İletişim Araçlarıyla Günlük Meşguliyet Değişkenine Göre Dindarlık ve Özgüven Puanları Arasındaki Kruskal Wallis H Testi Sonuçları

\begin{tabular}{|c|c|c|c|c|c|c|c|}
\hline Ölçek & $\begin{array}{l}\text { Meşguliyet } \\
\text { Durumu }\end{array}$ & $\mathrm{N}$ & Ort. & SS & Sira Ort. & $\overline{x^{2}}$ & $\mathrm{P}$ \\
\hline \multirow{5}{*}{ Dindarlık } & 1 saat & 5 & 4.50 & .474 & 81.80 & \multirow{5}{*}{6.574} & \multirow{5}{*}{0.160} \\
\hline & 2 saat & 33 & 4.26 & .382 & 59.70 & & \\
\hline & 3 saat & 41 & 4.39 & .316 & 72.04 & & \\
\hline & 4 saat & 34 & 4.25 & .438 & 61.40 & & \\
\hline & 5 saat ve üzeri & 23 & 4.46 & .507 & 82.43 & & \\
\hline \multirow{5}{*}{ Özgüven } & 1 saat & 5 & 3.96 & .544 & 71.50 & \multirow{5}{*}{3.030} & \multirow{5}{*}{0.553} \\
\hline & 2 saat & 33 & 3.79 & .356 & 65.12 & & \\
\hline & 3 saat & 41 & 3.92 & .467 & 75.13 & & \\
\hline & 4 saat & 34 & 3.72 & .512 & 60.63 & & \\
\hline & 5 saat ve üzeri & 23 & 3.84 & .620 & 72.50 & & \\
\hline
\end{tabular}

Tablo 12'ye baktığımızda İletişim araçlarıyla günlük meşguliyet değişkenine göre (1-5+ saat) aralığından meşguliyet süresini en az olarak ifade eden katılımcıların hem dindarlık puanlarının $(X=4,50)$ hem de özgüven puanlarının $(X=3.96)$ diğer katılımcılardan yüksek olduğu ve iletişim araçlarıyla daha az meşguliyetin dindarlığı ve özgüveni artırdığ iletişim araçlarıyla meşguliyet değişkeninin hem dindarlık üzerinde oluşturduğu fark $\left(\mathbf{x}^{2}=6.574\right.$; $\mathrm{P}=0.160 ; \mathrm{P}>0.05)$ hem de özgüven üzerinde oluşturduğu fark $\left(\mathrm{x}^{2}=3.030 ; \mathrm{P}=0.553 ; \mathrm{P}>0.05\right)$ istatistiksel açıdan anlamlı bulunmamıştır.

Araştırmanın beşinci sorusu "Özgüven ve dindarlı günlük kişisel gelişime (kitap okuma, kurs, seminer vb. etkinlikler) günlük ayrılan süreye göre değişmekte midir? ş̧eklindeydi.

Tablo 13: Kişisel Gelişime Günlük Ayrılan Süre Değişkenine Göre Dindarlık ve Özgüven Puanları Arasındaki Kruskal Wallis H Testi Sonuçları

\begin{tabular}{|c|c|c|c|c|c|c|c|}
\hline Ölçek & $\begin{array}{l}\text { Meşguliyet } \\
\text { Durumu }\end{array}$ & $\mathrm{N}$ & Ort. & SS & Sira Ort. & $\overline{x^{2}}$ & $\mathrm{P}$ \\
\hline \multirow{5}{*}{ Dindarlık } & 1 saat & 55 & 4.25 & .455 & 60.01 & \multirow{5}{*}{6.152} & \multirow{5}{*}{0.188} \\
\hline & 2 saat & 37 & 4.36 & .413 & 71.05 & & \\
\hline & 3 saat & 27 & 4.37 & .439 & 73.85 & & \\
\hline & 4 saat & 9 & 4.41 & .273 & 72.54 & & \\
\hline & 5 saat ve üzeri & 8 & 4.55 & .260 & 84.11 & & \\
\hline \multirow{5}{*}{ Özgüven } & 1 saat & 55 & 3.73 & .517 & 62.00 & \multirow{5}{*}{4.089} & \multirow{5}{*}{0.394} \\
\hline & 2 saat & 37 & 3.94 & .509 & 77.72 & & \\
\hline & 3 saat & 27 & 3.79 & .357 & 65.44 & & \\
\hline & 4 saat & 9 & 3.90 & .325 & 72.78 & & \\
\hline & 5 saat ve üzeri & 8 & 3.99 & .632 & 76.06 & & \\
\hline
\end{tabular}

Tablo 13'e baktığımızda kişisel gelişime günlük ayrılan süre değişkenine göre (1-5+ saat) aralığından meşguliyet süresini 5 saat ve üzeri olarak ifade eden katılımcıların hem dindarlık puanlarının $(X=4.55)$ hem de özgüven puanlarının $(X=3.99)$ diğer katılımcılardan yüksek olduğu ve kişisel gelişime günlük ayrılan sürenin artmasına bağlı olarak özgüvenin ve dindarlığın da arttığı görülmektedir. Ancak kişisel gelişime günlük ayrilan süre değişkeninin hem dindarlık üzerinde oluşturduğu fark $\left(\mathbf{x}^{2}=6.152 ; \mathrm{P}=0.188 ; \mathrm{P}>0.05\right)$ hem de özgüven üzerinde oluşturduğu fark $\left(\mathbf{x}^{2}=4.089 ; \mathrm{P}=0.394 ; \mathrm{P}>0.05\right)$ istatistiksel açıdan anlamlı bulunmamıştır. 
Araştırmanın altıncl sorusu "Özgüven ve dindarlık kişisel dindarlık algısına göre değişmekte midir?" şeklindeydi.

Tablo 14: Kişisel Dindarlık Algısı Değişkenine Göre Dindarlık ve Özgüven Puanları Arasındaki Kruskal Wallis H Testi Sonuçları

\begin{tabular}{|c|c|c|c|c|c|c|c|c|}
\hline Ölçek & $\begin{array}{c}\text { Kişisel Dindarlık } \\
\text { Algisı }\end{array}$ & $\mathrm{N}$ & Ort. & SS & Sira Ort. & $\overline{x^{2}}$ & $\mathrm{P}$ & Fark \\
\hline \multirow{5}{*}{ Dindarlık } & $\begin{array}{l}\text { Hiç dindar } \\
\text { değilim }\end{array}$ & - & - & - & - & \multirow{5}{*}{31.907} & \multirow{5}{*}{0.000} & \multirow{5}{*}{$\begin{array}{l}5>4 \\
5>3 \\
5>2\end{array}$} \\
\hline & Düşük düzey & 3 & 3.96 & .230 & 25.17 & & & \\
\hline & Orta düzey & 59 & 4.21 & .412 & 56.00 & & & \\
\hline & Dindarım & 64 & 4.38 & .353 & 73.08 & & & \\
\hline & Çok dindarım & 10 & 4.91 & .099 & 125.95 & & & \\
\hline \multirow{5}{*}{ Özgüven } & $\begin{array}{l}\text { Hiç dindar } \\
\text { değilim }\end{array}$ & - & - & - & - & \multirow{5}{*}{5.420} & \multirow{5}{*}{0.044} & \multirow{5}{*}{$\begin{array}{l}5>4 \\
5>3 \\
5>2\end{array}$} \\
\hline & Düşük düzey & 3 & 3.29 & .876 & 42.67 & & & \\
\hline & Orta düzey & 59 & 3.78 & .450 & 64.81 & & & \\
\hline & Dindarım & 64 & 3.84 & .492 & 69.43 & & & \\
\hline & Çok dindarım & 10 & 4.12 & .416 & 92.05 & & & \\
\hline
\end{tabular}

Tablo 14'e baktığımızda kişisel dindarlık algısı değişkenine göre kendini "çok dindar" olarak ifade eden katılımcıların hem dindarlık puanlarının $(X=4.91)$ hem de özgüven puanlarının $(X=4.12)$ diğer katılımcılardan yüksek olduğu; kişisel dindarlık algısının yükselmesine bağlı olarak dindarlık ve özgüveninde arttığ 1 ve de oluşan farkın hem dindarlıkta $\left(\mathbf{x}^{2}=31.907 ; \mathrm{P}=0.000 ; \mathrm{P}<0.05\right)$ hem de özgüvende $\left(\mathbf{x}^{2}=5.420 ; \mathrm{P}=0.44 ; \mathrm{P}<0.05\right)$ istatistiksel açıdan anlamlı olduğu görülmektedir.

Araştırmanın yedinci sorusu "Özgüven ve dindarlık pandemi sürecinin günlük hayata olumsuz etkisine yönelik algıya göre değişmekte midir?” şeklindeydi.

Tablo 15: Pandeminin Günlük Hayata Olumsuz Etki Algısı Değişkenine Göre Dindarlık ve Özgüven Puanları Arasındaki Kruskal Wallis H Testi Sonuçları

\begin{tabular}{|c|c|c|c|c|c|c|c|}
\hline Ölçek & $\begin{array}{l}\text { Pandeminin Günlük } \\
\text { Hayata Olumsuz } \\
\text { Etkisi Algisı Puanı }\end{array}$ & $\mathrm{N}$ & Ort. & SS & Sira Ort. & $\mathbf{x}^{2}$ & $\mathrm{P}$ \\
\hline \multirow{5}{*}{$\begin{array}{c}\text { Dini } \\
\text { Yönelim }\end{array}$} & 1 puan & 10 & 4.51 & .307 & 84.35 & \multirow{5}{*}{4.994} & \multirow{5}{*}{0.288} \\
\hline & 2 puan & 16 & 4.16 & .470 & 52.78 & & \\
\hline & 3 puan & 42 & 4.34 & .340 & 65.25 & & \\
\hline & 4 puan & 32 & 4.39 & .355 & 71.36 & & \\
\hline & 5 puan & 36 & 4.33 & .506 & 72.33 & & \\
\hline \multirow{5}{*}{ Özgüven } & 1 puan & 10 & 3.91 & .597 & 70.55 & \multirow{5}{*}{6.071} & \multirow{5}{*}{0.194} \\
\hline & 2 puan & 16 & 3.86 & .449 & 72.53 & & \\
\hline & 3 puan & 42 & 3.96 & .469 & 79.13 & & \\
\hline & 4 puan & 32 & 3.75 & .357 & 58.81 & & \\
\hline & 5 puan & 36 & 3.70 & .566 & 62.35 & & \\
\hline
\end{tabular}

Tablo 15'e baktığımızda pandeminin günlük hayata olumsuz etkisi değişkenine göre pandeminin etkisini (1-5) aralığından 1 olarak yani en az olarak ifade eden katılımcıların dindarlık puanlarının $(X=4.51)$ diğer katılımcılardan yüksek olduğu; pandeminin etkisini (1-5) aralığından 3 olarak yani orta düzey olarak ifade eden katılımcıların özgüven $(X=3.96)$ puanının diğer katılımc1lardan yüksek olduğu görülmektedir. Ancakpandeminin günlük hayata olumsuz etkisi değişkeninin dindarlık ve özgüven üzerinde oluşturduğu farkın hem dindarlıkta $\quad\left(\mathbf{x}^{2}=4.994\right.$; 
$\mathrm{P}=0.288 ; \mathrm{P}>0.05)$ hem de özgüvende $\left(\mathrm{x}^{2}=6.071 ; \mathrm{P}=0.194 ; \mathrm{P}>0.05\right)$ istatistiksel açıdan anlamlı olmadığı görülmektedir.

Araştırmanın sekizinci sorusu "Özgüven ve dindarlı, üniversite eğitiminde barınma yerine göre değişmekte midir?” şeklindeydi.

Tablo 16: Barınma Yeri Değişkenine Göre Dindarlık ve Özgüven Puanları Arasındaki Kruskal Wallis H Testi Sonuçları

\begin{tabular}{|c|c|c|c|c|c|c|c|}
\hline \\
\hline Ölçek & Barınma Durumu & $\mathrm{N}$ & Ort. & SS & Sira Ort. & $\mathbf{x}^{2}$ & $\mathrm{P}$ \\
\hline \multirow{4}{*}{ Dindarlık } & Aile & 18 & 4.49 & .379 & 82.78 & \multirow{4}{*}{4.101} & \multirow{4}{*}{0.251} \\
\hline & $\begin{array}{c}\text { Özel } \\
\text { yurt/pansiyon }\end{array}$ & 14 & 4.19 & .495 & 57.75 & & \\
\hline & $\begin{array}{c}\text { Devlet } \\
\text { yurdu/pansiyon }\end{array}$ & 91 & 4.34 & .408 & 68.60 & & \\
\hline & Kiralık daire & 13 & 4.27 & .324 & 59.58 & & \\
\hline \multirow{4}{*}{ Özgüven } & Aile & 18 & 3.87 & .405 & 69.42 & \multirow{4}{*}{0.684} & \multirow{4}{*}{0.877} \\
\hline & $\begin{array}{c}\text { Özel } \\
\text { yurt/pansiyon }\end{array}$ & 14 & 3.86 & .452 & 76.43 & & \\
\hline & $\begin{array}{c}\text { Devlet } \\
\text { yurdu/pansiyon }\end{array}$ & 91 & 3.82 & .505 & 67.16 & & \\
\hline & Kiralık daire & 13 & 3.78 & .542 & 68.08 & & \\
\hline
\end{tabular}

Tablo 16'ya baktığımızda barınma yeri değişkenine göre ailesinin yanında kalan katılımcıların hem dindarlık puanlarının $(X=4.49)$ hem de özgüven puanlarının $(X=3.87)$ diğer katılımcilardan yüksek olduğu ancak oluşan farkın hem dindarlıkta $\left(\mathbf{x}^{2}=4.101 ; \quad \mathrm{P}=0.251\right.$; $\mathrm{P}>0.05)$ hem de özgüvende $\left(\mathbf{x}^{2}=0.684 ; \quad \mathrm{P}=0.877 ; \quad \mathrm{P}>0.05\right)$ anlamlılık düzeyine ulaşmadığ 1 görülmektedir.

Araştırmanın dokuzuncu sorusu "Özgüven ve dindarlık arasındaki ilişki anlamlı mıdır?" şeklindeydi.

Tablo 17: Özgüven ve Dindarlık Ölçekleri Arasındaki Korelasyon

\begin{tabular}{|l|c|c|c|c|}
\hline \multicolumn{3}{|c|}{} & Dindarlık & Özgüven \\
\hline \multirow{3}{*}{ Spearman's rho } & \multirow{2}{*}{ Dindarlık Ortalama } & Correlation Coefficient & 1.000 & .145 \\
\cline { 3 - 5 } & & Sig. (2-tailed) &. & .093 \\
\cline { 3 - 5 } & \multirow{3}{*}{ Özgüven Ortalama } & Correlation Coefficient & .136 & 136 \\
\cline { 3 - 5 } & & Sig. (2-tailed) & .093 & 1.000 \\
\cline { 3 - 5 } & & $\mathrm{N}$ & 136 & 136 \\
\hline
\end{tabular}

Tablo 17 özgüven ile dindarlık arasında istatistiksel açıdan anlamlılık düzeyine ulaşan güçlü bir ilişki olmadığını $(r=0.145 ; \mathrm{p}=0.93 ; \mathrm{p}>0.05)$ göstermektedir.

Araştırmanın onuncu sorusu "Örneklemin genel olarak özgüven ve genel dindarlık düzeyi nedir? " şeklindeydi.

Tablo 18: Özgüven ve Dindarlık Ölçeklerinin Ortalama Puanları

\begin{tabular}{|l|l|l|l|}
\hline Ölçek & $\mathrm{N}$ & $\mathrm{X}$ & $\mathrm{S}$ \\
\hline Dindarlık & 136 & 4.34 & 0.409 \\
\hline Özgüven & 136 & 3.83 & 0.487 \\
\hline
\end{tabular}


Tablo 18'e bakıldığında her iki ölçeğinde 5'li likert tipi olduğu göz önüne alındığında 5 üzerinden $(\mathrm{x}=4.34)$ puanla dindarllğın ve de (3.83) puanla özgüvenin yüksek düzeyde ortalamaya sahip oldukları görülmektedir.

\section{Tartışma}

Araştırmamızda interaktif olarak seçkisiz şekilde seçilen katılımcıların özgüven - dindarlık düzeyleri arasındaki ilişkiyi ve özgüven ile dindarlık üzerinde "cinsiyet, ekonomik durum, memleketin bulunduğu coğrafi bölge, iletişim araçlarıyla günlük meşguliyet süresi, kişisel gelişime (kitap okuma, kurs, seminer vb. etkinlikler) günlük ayrılan süre, kişisel dindarlık algısı, pandemi sürecinin günlük hayata olumsuz etkisine yönelik alg1, barınma yeri” değişkenlerinin oluşturacağı farklar incelenmiş olup bulgularla ilgili tartışmalar şu şekildedir:

\section{Cinsiyet - Özgüven / Dindarlık İlişkisisi:}

Cinsiyet değişkenine göre erkek katılımcıların dindarlık puanlarının kızlardan yüksek olduğu $(X=4.38)$; kızlarrın özgüven puanlarının ise erkeklerden yüksek olduğu $(X=3.85)$ ancak hem dindarlık ( $U=1417.0000 ; p=0.608 ; \quad p>0.05)$ hem de özgüven üzerinde ( $U=1428.500$; $\mathrm{p}=0.653 ; \mathrm{p}>0.05)$ cinsiyet değişkeninin oluşturduğu farkın istatistiksel açıdan anlamlılık düzeyine ulaşmadığ görülmektedir.Özgüven konusuyla ilgili (Pişkin, 1996; Sarıçam ve Güven, 2012; Gürler, 2015; Acar, 2019) yaptıkları araştırmalarda erkek öğrencilerin özgüven düzeylerini anlamlı şekilde yüksek bulurken; (Esentaş vd., 2017) kızların özgüvenlerini anlamlı şekilde yüksek bulmuştur. Yine cinsiyetin özgüven üzerindeki etkisinin araștırıldığı (Karademir, 2015; Bulut, 2017; Doğru, 2017, Bostancı vd., 2018; Gencer, 2019b; Ünverdi, 2020)'nin çalışmalarında araştırma sonucumuzu da destekler şekilde cinsiyetin özgüven üzerinde oluşturduğu fark anlamlı bulunmamıştır. Aynı şekilde (Sarıçam ve Güven, 2012) ve (Acar, 2019) tarafindan yapilan araştırmalarda tespi edilen cinsiyetin dindarlık üzerinde anlamlı fark oluşturmadığ 1 sonucu da araştırmamızı desteklemektedir. Cinsiyet kavramı fizyolojik farklılık yanında sosyal, zihinsel, bilişsel ve mental farklılıklarla da ilişkilendirilen bir kavram olarak karşımızda durmaktadır. Özellikle toplumun bakış açısına göre şekillenen cinsiyet rolleri, bireylerin duygu, düşünce ve psikolojik yapıları üzerinde de belirgin olarak kendini hissettirmekte ve bireylerde toplumun tanımladığı cinsiyet rolleri bağlamında şekillenen bir psikososyal yapı ortaya çıkmaktadır. Erkeklerin kadınlara nazaran toplumun sağladığı daha geniş bir alan içerisinde ve daha özgür bir atmosfer içerisinde gelişimlerini sürdürdükleri kabul edilebilir bir durumdur. Bu bağlamda erkek katılımcıların özgüven düzeylerinin yüksek çıkması beklenirken kızların özgüvenlerinin yüksek çıkmasını; özellikle son dönemlerde kadın haklarına yönelik hukuki düzenlemeler, kadınların sosyal ve ekonomik hayat içerisinde daha fazla sorumluluk almaları, sosyal medyanın kadın problemlerine yönelik farkındalık artırıcı yayınlara ağırlık vermesi, katılımcıların öğretmen adayları oldukları düşünüldüğünde son yıllarda öğretmenlik mesleğinde oranın kadınlar lehine yükseliyor olması gibi kızlar açısından pozitif gelişmelerle ilişkilendirmenin mümkün olacağı düşünülmektedir. Diğer taraftan dindarlık düzeyinin erkeklerde daha yüksek çıkmasını, özellikle cami gibi ibadet alanlarında erkeklerin daha rahat ibadet edebilmeleri ve dini ritüellere katılım konusunda daha avantajlı olmaları bağlamında değerlendirmek mümkündür. Ayrıca bu sonuca; aile geçiminin ilk sırada erkeklerin bir sorumluluğu olarak algılanması da erkek katılımcıların mezuniyet sonrası görev almada kızlardan daha çok baskı hissetmeleri ve bu baskının oluşturduğu travmatik sürecin onları bir başa çıkma unsuru olarak dine yönlendirmesi olarak bakmak yerinde olacaktır. Ancak farkın hem dindarlık hem de özgüvende anlamlılık düzeyinde olmamasını, kadın ya da erkek olmanın tek başına insanın dindarlığının ve özgüveninin kaynağı olamayacağı şeklinde açıklamak mümkündür. Zira dindarlık ve özgüven, pek çok farklı kanallardan beslenen ve şekillenmesinde çok farklı argümanların rol oynadığı kavramlardır ve bu kavramları sadece cinsiyetle sınırlandırarak açıklamak mümkün görünmemektedir. 


\section{Ekonomik durum - Özgüven / Dindarlık İlişskisi:}

Ekonomik durum değişkenine göre ekonomik durumunu "yüksek" olarak ifade eden katılımcıların hem dindarlık puanlarının $(X=4.46)$ hem de özgüven puanlarının $(X=4.05)$ diğer katılımcılardan yüksek olduğu ve ekonomik düzeyin artmasına bağlı olarak dindarlık ve özgüveninde arttı̆g ancak oluşan farkın dindarlıkta $\left(\mathbf{x}^{2}=2.370 ; \quad \mathrm{P}=0.306 ; \mathrm{P}>0.05\right)$ anlamlılık düzeyine ulaşmadığ1; özgüvende ise $\left(\mathbf{x}^{2}=4.267 ; \mathrm{P}=0.042 ; \mathrm{P}<0.05\right)$ anlamlılık düzeyine ulaştı $\breve{1}$ görülmektedir. Ekonomik durum, bireyin hem gelişim süreci içerinde gereksinimlerinin karşılanması bakımından hem de toplumsal statü bakımından son derece önem arz eden bir argümandır. Bireylerin temel ihtiyaçlarının yeterli düzeyde karşılanması, sağlık hizmetlerinden yararlanma, giyim, barınma, kişisel bakım, kişisel gelişim, eğitim vb. sosyal hayatın her alanında bireylere avantaj sağlayan bir unsur olarak ekonomik durum; kişilerin gelecekle ilgili beklentileri, hayallerin gerçekleşmesi gibi psikolojik arka planı olan hususlarda da karşıllı̆̆ bulunan bir konudur. Ekonomik durumu yüksek olan bireylerin, ekonomik yetersizlik bağlamında ortaya çıkabilecek problemlerden uzak olmaları, toplumda daha yüksek statüde kabul görmeleri onların özgüvenlerini de besleyen bir unsur olarak düşünülebilir. Diğer taraftan ekonomik durumun yükselmesine bağlı olarak dindarlık puanlarının da arttığı görülmektedir. Dindarlığın pek çok ritüelinin ekonomik durumla ilişkili olduğu bilinen bir gerçekliktir. Örneğin İslam'da zekat, sadaka, kurban, hayır kurumları inşa etme gibi ibadetleri ekonomik olanaklar bağlamında değerlendirmek gerekmektedir. Dolayısıyla ekonomik durumun yükselmesine bağlı olarak dindarlık puanlarının artışını bu çerçevede düşünebiliriz. Ancak ekonomik durum değişkeninin dindarlık da oluşturduğu farkın anlamlı çıkmaması, dindarlığı tamamen ekonomik bir temel üzerine inşa edemeyeceğimizi, zenginliğin dindarlık için yeterli ve kapsayıcı bir açıklama olmayacağını ifade etmek mümkündür.

\section{Memleketin bulunduğu coğrafi bölge - Özgüven / Dindarlık İlişkisi:}

Memleketin bulunduğu coğrafi bölge değişkenine göre en yüksek dindarlık puanına Marmara Bölgesi katılımcılarının(X=4.28), en yüksek özgüven puanına ise Ege Bölgesi katılımcılarının $(X=4.65)$ sahip olduğu görülmektedir. Fakat coğrafi bölge değişkeninin hem dindarlık üzerinde oluşturduğu fark $\left(\mathbf{x}^{2}=3.774 ; \mathrm{P}=0.707 ; \mathrm{P}>0.05\right)$ hem de özgüven üzerinde oluşturduğu fark $\left(\mathbf{x}^{2}=8.665 ; \mathrm{P}=0.193 ; \mathrm{P}>0.05\right)$ istatistiksel açıdan anlamlı bulunmamıştır. Coğrafi bölge değişkeninin özgüven ile ilişkilendirilebilecek kavramlardan olduğunu varsaydığımız özdenetim üzerinde fark oluşturmaması tespiti de (Yakut, 2019) araştırmamızı dolaylı olarak destekler niteliktedir. Yerleşim yerleri ve yerleşim yerlerinin bulunduğu coğrafi bölgeler iklim, bitki örtüsü, ulaşım, barınma, giyim, iş olanakları gibi hem fizyolojik hem de psikososyal yapıyı etkileme potansiyeli olan bir değişkendir. Örneğin doğal bitki örtüsünün daha yoğun olarak bulunduğu yerlerin insan sağlığı açısından daha avantajlı olduğu; iklimlerin insan mizacinı etkilediği ve sıcak iklimde yaşayanların daha sempatik oldukları ve de yakın ilişkiler kurma konusunda daha başarılı oldukları gibi hususlar genel kabul gören hususlardır. Ancak doğal bitki örtüsü yoğunluğunun bazı insanların sağlığı açısından da risk barındırdığı, sıcak iklimde yaşayan her insanın insani ilişkilerde aynı başarıyı gösteremedikleri gerçeğinden hareketle coğrafi bölge bazında insanlar açısından genelleyici bir yaklaşımda bulunmanın mümkün olmadığını dile getirmek mümkündür. Bu bağlamda araştırma sonucumuzu da dikkate alarak dindarlık ve özgüven gibi psikososyal anlamda çok zengin alt yapısı bulunan kavramları coğrafi bölge değişkenine göre şekillendirmenin ve bu konuda genel geçer yargılarda bulunmanın mümkün olmadığını dile getirmek konuya sağlıklı bir yaklaşım açısından önem arz etmektedir.

\section{İletişim araçlarıyla günlük meşguliyet süresi- Özgüven / Dindarlık İlişkisi:}

İletişim araçlarıyla günlük meşguliyet değişkenine göre (1-5+ saat) aralığından meşguliyet süresini en az olarak ifade eden katılımcıların hem dindarlık puanlarının $(X=4.50)$ hem de özgüven puanlarının (X=3.96) diğer katılımcılardan yüksek olduğu ve iletişim araçlarıyla daha az meşguliyetin dindarlığı ve özgüveni artırdığı görülmektedir. Fakat iletişim araçlarıyla meşguliyet değişkeninin hem dindarlık üzerinde oluşturduğu fark $\left(\mathrm{x}^{2}=6.574 ; \mathrm{P}=0.160 ; \mathrm{P}>0.05\right)$ hem de 
özgüven üzerinde oluşturduğu fark $\left(\mathbf{x}^{2}=3.030 ; \mathrm{P}=0.553 ; \mathrm{P}>0.05\right)$ istatistiksel açıdan anlamlı bulunmamıştır. İletişim araçları modern dünyada kendisine yer edinmiş ve tüm insanlığın günlük yaşamının ayrılmaz bir parçası haline gelmiş bir değişkendir. Hemen hemen her insanın sıklığı farkl1lık arz etmekle birlikte iletişim araçlarıyla ilişkisi söz konusudur. Sorgulanan ve anlamlandırılmaya çalışılan iletişim araçlarıyla meşguliyet süresinin insanın bireysel ve toplumsal hayatında negatif ya da pozitif yönlü karşıllı̆ının ne olduğudur. Burada yine katılımcıların üniversite ögrencileri olmaları nedeniyle ders materyallerine ulaşım, araştırma gibi faaliyetlerde iletişim araçlarına sıklıkla başvurdukları öngörülebilir. Ancak burada bilgi kirliliğinin ve güvenlik konusunda risk barındıran sanal ortam gerçekliği de vardır. İnsanın sanal alemde kalma süresinin armasına bağlı olarak olumsuzluklarından etkilenme olasılığı da artacaktır. Fakat iletişim araçlarıyla meşguliyet süresinin özgüven ve dindarlık da anlamlı fark oluşturacak yeterlilikte olmadığı görülmektedir. $\mathrm{Bu}$ durum daha çok bireysel anlamda sanal ortamın olumsuzlukları konusunda ki farkındalıkla ilgilidir. Kendi potansiyellerinin farkında olan ve iletişim araçlarının olumsuz atmosferinden kendini koruyabilecek donanıma sahip kişiler için sanal ortamdan olumsuz olarak etkileneceklerini kesin olarak ifade etmek mümkün değildir. $\mathrm{Bu}$ da daha çok iletişim araçlarıyla meşguliyette nicelikten ziyade nitelikle ilişkisini göstermektedir. Örneğin güvenli sitelerden sadece kendini geliştirme amaçlı online eğitimler alan ya da online olarak kütüphanelere bağlanarak araştırma yapan bir üniversite öğrencisinin iletişim araçlarıyla meşguliyet süresinin fazla olmasının herhangi bir olumsuz yansımalarından söz etmek mümkün görünmemektedir. Dolayısıyla araştırmamızda iletişim araçlarıyla meşguliyet süresinin oluşturduğu farkın anlamlı bulunmamasının nicelikten ziyade niteliğe atıf yapan bir gösterge olarak değerlendirmek gerekmektedir.

\section{Kişisel gelişime (kitap okuma, kurs, seminer vb. etkinlikler) günlük ayrılan süre - Özgüven / Dindarlık İlişkisi:}

Kişisel gelişime günlük ayrılan süre değişkenine göre (1-5+ saat) aralığından meşguliyet süresini 5 saat ve üzeri olarak ifade eden katılımcıların hem dindarlık puanlarının $(X=4.55)$ hem de özgüven puanlarının $(X=3.99)$ diğer katılımcılardan yüksek olduğu ve kişisel gelişime günlük ayrılan sürenin artmasına bağlı olarak özgüvenin ve dindarlığın da arttığ 1 görülmektedir. Ancak kişisel gelişime günlük ayrılan süre değişkeninin hem dindarlık üzerinde oluşturduğu fark $\left(\mathbf{x}^{2}=6.152 ; \quad \mathrm{P}=0.188 ; \mathrm{P}>0.05\right)$ hem de özgüven üzerinde oluşturduğu fark $\left(\mathbf{x}^{2}=4.089 ; \mathrm{P}=0.394\right.$; $\mathrm{P}>0.05$ )istatistiksel açıdan anlamlı bulunmamıştır. İnsan, genetik olarak taşıdığı özellikleri yaşam süreci içerisinde işlevsel kılmaya çalışan ve yeni kazanımlar elde etme amacı taşıyan bir varlıktır. İnsanın bu süreçteki başarısını belirleyen en temel unsur kişisel özveri ve emektir. Potansiyellerle ilgili farkındalık da yine insanın çalışmasına bağlı olarak elde edilen bir kazanımdır. Bu durumu da özellikle kişisel gelişime yönelik faaliyetlerle ilişkilendirmek mümkündür. Herhangi bir kişisel gelişim faaliyetinde bulunmayan bireyin kendini tanıması, potansiyelleri konusunda yeterli düzeyde farkındalık oluşturması beklenemez. Bu bağlamda güçlü ve zayıf yönlerini bilmeyen bir kişinin de hangi yönünü ne ölçüde güçlendirmesi gerektiği ve bunun için yapması gereken şeylerin bilincinde olması mümkün görünmemektedir. Buna ilaveten kişisel gelişim için sarf edilen çaba, insanın pek çok psikososyal boyutunda pozitif olarak karşılık bulacağı gibi psikososyal yapısının da bir parçası olarak değerlendirebileceğimiz özgüven ve dindarlıkta da karşılığı olması kabul edilebilir bir durumdur. Dolayısyla kişisel gelişime ayrılan süreye bağlı olarak özgüven ve dindarlık düzeyinin de artması bu düşünceyi desteklemektedir. Ancak oluşan farkın anlamlılık düzeyinde olmaması, kişisel gelişime ayrılan sürenin özgüven ve dindarlığın yordayıcısı olmadığını bizlere göstermektedir.

\section{Kişisel Dindarlık Algısı - Özgüven / Dindarlık İlişkisi:}

Kişisel dindarlık algısına göre kendini "çok dindar" olarak ifade eden katılımcıların hem dindarlık puanlarının $(X=4.91)$ hem de özgüven puanlarının $(X=4.12)$ diğer katılımcılardan yüksek olduğu; kişisel dindarlık algısının yükselmesine bağlı olarak dindarlık ve özgüveninde arttığı ve de 
oluşan farkın hem dindarlıkta $\left(\mathbf{x}^{2}=31.907 ; \mathrm{P}=0,000 ; \mathrm{P}<0.05\right)$ hem de özgüvende $\left(\mathbf{x}^{2}=5.420 ; \mathrm{P}=0.44\right.$; $\mathrm{P}<0.05)$ istatistiksel açıdan anlamlı olduğu görülmektedir. İnsanı bireysel ve toplumsal anlamda güçlü kılan hususlardan birisi olarak kendisiyle ilgili farkındalığının yüksek olması gösterilebilir. İnsanın çok boyutlu yapısı içerisinde güçlü ve zayıf yönlerini bilmesi olarak anlamlandırabileceğimiz kendilik algısı, kişiye potansiyellerini kullanma ve zayıf yönlerini de geliştirme olanağı sunan bir kazanımdır. Özellikle dindarlık gibi çok farklı kaynaklardan beslenen; duygu, düşünce, davranış, bilgi ve inanç boyutları olan; hayata bakış ve varlığı anlamlandırma konularında zihinsel şemalar sunan bir konuda, "çok dindar" olarak güçlü bir meydan okumada bulunabilmek hiç şüphesiz üst düzey bir kendilik algısı gerektirmektedir. Bu bağlamda kendini çok dindar olarak tanımlayan bir kişide de üst düzey kendilik algısı olduğunu varsaymak mümkün görünmektedir. Ayrıcakişinin dindarlık durumunu yüksek düzeyde konumlandırması, her ne kadar subjektif yönlü bir husus olsa da, kişinin özgüven düzeyinin yükselmesini etkileyebilecek bir motivator olarak rol oynadığını söylemek mümkündür. Dolayısıyla araştırmamıza göre kişisel dindarlık algısının oluşturduğu anlamlı fark; yüksek düzey bir kişisel dindarlık algısının, dindarlık ve özgüvenin yordayıcısı olduğunu bizlere göstermektedir. Buna ilaveten yapılan araştırmalarda özgüvenle dolaylı olarak ilişkilendirebileceğimiz benlik saygısı (Ball vd., 2003; Şahin, 2005), empati (Şahin, 2008) ve öz-denetim ile kişisel dindarlık algısı arasında tespit edilen pozitif yönlü anlamlı ilişki de araştırmamızın sonucunu destekler niteliktedir.

\section{İlişkisi:}

Pandemi sürecinin günlük hayata olumsuz etkisine yönelik algı - Özgüven / Dindarlık

Pandeminin günlük hayata olumsuz etkisine göre pandeminin etkisini (1-5) aralığından 1 olarak yani en az olarak ifade eden katılımcıların dindarlık puanlarının $(X=4.51)$ diğer katılımcılardan yüksek olduğu; pandeminin etkisini (1-5) aralığından 3 olarak yani orta düzey olarak ifade eden katılımcıların özgüven $(X=3.96)$ puanının diğger katılımcılardan yüksek olduğu görülmektedir. Ancak pandeminin günlük hayata olumsuz etkisi değişkeninin dindarlık ve özgüven üzerinde oluşturduğu farkın hem dindarlıkta $\left(\mathbf{x}^{2}=4.994 ; \mathrm{P}=0.288 ; \mathrm{P}>0.05\right)$ hem de özgüvende $\left(\mathbf{x}^{2}=6.071 ; \mathrm{P}=0.194 ; \mathrm{P}>0.05\right)$ istatistiksel açıdan anlamlı olmadığı görülmektedir. İnsan çevredeki uyarıcılara yüklediği olumlu ya da olumsuz anlamın tonunu ve şiddetini psikolojik dünyasında hisseden bir varlıktır. İnsanların psikososyal düzeylerindeki farklılık onların tehdit algıları üzerinde de kendini göstermektedir. Bazı olaylar, insanların bir kısmını üst düzey bir şiddette etkilerken, bir kısmı için ise önemsenecek bir değerde dahi görülmeyebilir. Bu durum insanların uyarcılclara yükledikleri olumlu /olumsuz ya da tehdit algılarının düzeyiyle ilgilidir. Bu bağlamda katılımcıların genel olarak pandemi sürecinin günlük hayata olumsuz etkisini düşük düzeyde algılamalarına bağlı olarak özgüven ve dindarlık puanlarının yüksek çıkmasını ilişkilendirmek mümkündür. Ancak oluşan farkın anlamlı bulunmaması; herhangi bir olayı sadece o olayla ilgili geliştirilen alg1 düzeyiyle açıklamanın yetersiz olduğunu göstermektedir. Bu bağlamda pandemi sürecinin günlük hayata olumsuz etkileriyle ilgili alg1, özgüven ve dindarlık üzerinde belirli bir etki oluşturmuş ancak özgüven ve dindarlığı bir bütün olarak yordamada yetersiz kalmıştır.

\section{Barınma Yeri - Özgüven / Dindarlık İlişkisi:}

Barınma yeri değişkenine göre ailesinin yanında kalan katılımcıların hem dindarlık puanlarının $(X=4.49)$ hem de özgüven puanlarının $(X=3.87)$ diğer katılımcılardan yüksek olduğu ancak oluşan farkın hem dindarlıkta $\left(\mathbf{x}^{2}=4,101 ; \mathrm{P}=0.251 ; \mathrm{P}>0.05\right)$ hem de özgüvende $\left(\mathbf{x}^{2}=0.684\right.$; $\mathrm{P}=0.877 ; \mathrm{P}>0.05$ )anlamlılık düzeyine ulaşmadığ 1 görülmektedir. Barınma yeri, tüm çevresel uyarıcılarda olduğu gibi mekânın psikolojik yönü bağlamında değerlendirilebilecek bir konu olmasının yanında sosyal ilişki yoğunluğu, görev paylaşımı, sorumluluk bilinci gibi konularda da karşılığı bulunan bir değişkendir. Bu bağlamda kalınan yerin genişliği, aydınlık durumu, yap1 malzemesi gibi etkenler insanın fizyolojik yönünü ve buna bağlı olarak duygu, düşünce ve zihinsel yönünü de etkileyebilecek potansiyel barındırır. Yine kalabalık ortamlar, bir sosyalleşme aracı olabileceği gibi farklı problemlerin gelişmesine de neden olabilir. Özellikle insanın en temel 
ihtiyaçlarından olan sevgi ve güvenlik ihtiyacının yeterli düzeyde karşılanması sağlıklı bir psikosoyal yapı için son derece önem arz etmektedir. Bu bağlamda ailesinden uzakta barınmak durumunda kalan bir üniversite öğrencisinin ailesinin sunduğu sevgi ve güvenlik gibi psikolojik alt yapısı bulunan ihtiyaçlarının yeterli düzeyde karşılaması bir problem olarak ortaya karşımızda durmaktadır. Bunun yanı sıra beslenme, giyim, barınma vb. konularda da farklı problemler görülebilir. Dolayısıyla tüm bu olası problemler, üniversite öğrencilerinin psikososyal yapılarını kaçınılmaz olarak etkileyecektir. Özellikle ailesinin yanında kalan öğrencilerin bir psikolojik yapı göstergesi olarak da kabul edebileceğimiz özgüven ve dindarlık düzeylerinin yüksek olması bu görüşü destekler niteliktedir. Fakat değişkenin oluşturduğu farkın anlamlılık düzeyinde olmamasını; aileden uzakta barınmanın her zaman olumsuz karşılığının olmayacağı diğer bir ifade ile ailenin belirli kurallarına bağlı olmaksızın daha özgür bir hayat yaşama olanağının ailenin yanında barınmanın sağladığ 1 avantaj kadar önemli hale gelebildiği şeklinde değerlendirmek de mümkündür. Dolayısıyla ailenin yanında ya da uzağında barınmak, avantaj / dezavantaj algısı bireylere göre değişen ve özgüven ile dindarlığ 1 açıklayabilecek güçte olmayan bir husus olarak ifade edilebilir. Barınma yeri değişkeninin özgüven ile ilişkilendirilebilecek kavramlardan birisi olarak değerlendirebileceğimiz özdenetim üzerinde anlamlı fark yaratmadığına dair tespit de (Yakut, 2019) araştırma sonucumuzu dolaylı olarak desteklemektedir.

\section{Özgüven - Dindarlık İlişskisi:}

Özgüven ile dindarlık arasında istatistiksel açıdan anlamlılık düzeyine ulaşan güçlü bir ilişki olmadığı $(r=0.145 ; \mathrm{p}=0.93 ; \mathrm{p}>0.05)$ tespit edilmiştir. Konuyla ilgili (Sarıçam ve Güven, 2012; Bulut, 2017; Esati, 2017; Acar, 2019) tarafından yapılan araştırmalarda, özgüven ile dindarlık arasındaki ilişkinin pozitif yönlü ve anlamlılık düzeyine ulaştığı görülmektedir ve bu sonuçlar araştırmamızın literatür tarafından desteklenmediği anlamına gelmektedir. $\mathrm{Bu}$ farklı yansımaları katılımcıların özellikleri bağlamında değerlendirmek mümkündür. Özellikle günümüzde üniversite atmosferinde psikososyal dünyalarının inşasında çok farklı argümanların rol oynadığ 1 ve buna bağlı olarak çok zengin kanallardan beslenen bir duygu, düşünce ve bilişsel yapılarının söz konusu olduğu genel olarak üniversite öğrencileri özel olarak da ilahiyat öğrencileri üzerinde etkisini baskın olarak hissettiren unsurlar arasında dindarlığın yer almadığını bizlere göstermektedir. Tabi ki bu durum dindarlığın özgüven ile hiçbir ilişkisinin olmadığı anlamına gelmemekle birlikte, ilahiyat öğrencilerinin özgüveni de kapsayan psikososyal yapıları üzerinde dindarlığın anlamlı fark oluşturabilecek güçte bir etken olmadığını ifade etmektedir.

\section{Genel Özgüven ve Genel Dindarlık Düzeyi:}

Her iki ölçeğinde 5'li likert tipi olduğu göz önüne alındığında 5 üzerinden $\quad(x=4.34$; \%86.8) puanla dindarlığın ve de $(3.83 ; \% 76.6)$ puanla özgüvenin yüksek düzeyde ortalamaya sahip olduklarını göstermektedir. Özgüven, insanın yaşam sürecinde kendine inanması, kendini güçlü hissetmesi ve karşılaştığı problemlerle daha cesaretle yüzleşebilmesi bağlamında değerlendirilen bir duygusal kapasitedir. Özgüvenin düşük olması, içsel bir bütünlük kuramamanın sonucu içsel çatışmalar yaşama ve psikososyal problemler karşısında acziyet içerisinde bulunma anlamına gelir. $\mathrm{Bu}$ durum insanın hem fizyolojik hem de psikolojik sağlığı açısından ciddi riskler barındırmaktadır. Diğer taraftan güçlü bir özgüvene sahip bireylerin hem kendileriyle barışık olması hem de çevreleriyle daha etkili bir iletişim kurmaları beklenir. Buna bakarak onların başarı ve mutluluk konusunda daha avantajlı bir konuma yükseleceklerini öngörmek mümkündür. Yine dindarlık da karşılaşılan problemlerle yüzleşme konusunda dini, bir başa çıkma unsuru olarak kullanmayı beraberinde getiren bir husustur. $\mathrm{Bu}$ bağlamda dindarlık düzeyi yüksek olan bireylerin problemlerden diğer bireylere nazaran daha az etkilenecekleri öngörülebilir. Sonuç olarak katılımcıların hem özgüvende hem de dindarlık da sahip oldukları yüksek ortalama, onların psikososyal anlamda güçlü yapılarının bir göstergesi olarak kabul edilebilir. Buna göre de pandemi atmosferinin katılımcıların hem eğitim süreci üzerinde hem de psikososyal yapıları üzerinde güçlü bir etki oluşturmayacağı öngörüsünde bulunmak mümkündür. 


\section{Sonuç ve Öneriler}

İnsan sosyal ve psikolojik yönlü bir varlıktır ve bunun bir yansıması olarak duygu, düşünce ve davranış dünyasının şekillenmesinde çok farklı argümanlar rol oynamaktadır. Hayatının her ânına sosyal ve psikolojik bir anlam yükleme, tüm insanlar için ortak bir davranıştır. Fakat bu davranışın düzeyini, sınırlarını, tonunu ve şiddetini belirleyen etken ise, insanların bireysel farklılık arz eden psikososyal yapılarıdır. İnsan, doğuştan kalıtımsal olarak getirdiği özelliklerinin etkisini tüm yaşantısında hissetmektedir. Yine yaşantısında etkisini hissettiği unsurlardan birisi de sosyal hayatında çok zengin etkileşimlerinden elde ettiği kazanımlardır. İnsanın sosyal, bilişsel, duygusal, düşünsel yapısının şekillenmesinde hangi etkenin ne ölçüde rol oynadığını kesin olarak ifade etmek mümkün olmasa da, hayatındaki her şeyin onun psikososyal dünyasında farklı oranlarda da olsa bir karşılığının olduğunu dile getirmek mümkündür. Bu bağlamda araştırma konumuzun kavramları olarak özgüven ve dindarlık, hem potansiyellerin bir dışa vurumu hem de sosyal etkileşimlerin şekillendirdiği bir kazanım olarak bireylerin hayatlarında önemi tartışılmaz psikososyal iki değer şeklinde ön plana çıkmaktadır. Zira özgüven ve dindarlığın, insanın duygu, düşünce ve davranış olarak tüm hayatını etkileme potansiyeli söz konusudur. İnsanların potansiyellerinin açığa çıktığı ve bu potansiyellerin âdeta test edildiği zaman dilimleri olarak travmatik süreçleri göstermek mümkündür. Travmatik süreçler, özellikle bireysel sınırların ötesinde toplumsal ve hatta küresel bir güç haline dönüşmüş ise, bireylerin potansiyellerinin daha da önem ve anlam kazanması söz konusudur. Bu bağlamda içinde bulunduğumuz Covid-19 olarak adlandırılan pandemi sürecinin tüm dünyada bireysel ve toplumsal hayatı tehdit eden bir düzeye evrilmesi, pandeminin insan üzerinde fizyolojik ve psikolojik pek çok rahatsızlık riskine ivme kazandırmaktadır. Bundan dolayı bu problemler sarmalının insanlar üzerindeki etkilerinin araştırılması son derece önem arz eden bir husustur. Özellikle öğretmen ve din görevlisi adayı olarak konumlandırabileceğimiz İlahiyat Fakültesi öğrencileri üzerinde pandemi sürecinin oluşturacağı bir psikososyal problemin etki sınırlarını öngörmek mümkün olmadığından, bu problemin bireysel etkileri dışında eğitimci ve din görevlisi misyonlarını sağlıklı ve amaçlara uygun olarak yerine getirmeleri önünde de bir risk oluşturacağı unutulmamalıdır. Bu bağlamda araştırmamız sadece ilahiyat öğrencileri örneklemi üzerinde yapıldığından sonuçları açısından bir sınırlılık taşısa da, ilahiyat fakültesi öğrencilerinin pandemi süreciyle ilişkisine ve bu sürecin onlar üzerindeki etki düzeyine cevap niteliğindeki çalışmamızın verileri, hem pandemi süreciyle ilgili literatüre hem de özgüven ve dindarlık alanlarıyla ilgili literatüre katkı niteliği taşımaktadır.

Araştırma; özgüven ve özgüvenle ilişkilendirilen kavramlardan birisi olarak dindarlığın İlahiyat Fakültesi öğrencileri üzerindeki etkilerini çeşitli değişkenler açısından inceleme ve anlama amacı taşımaktadır. Araştırmanın örneklem grubu; Yozgat Bozok Üniversitesi İlahiyat Fakültesi'nin iletişim araçları aracılığıyla seçkisiz olarak seçilen 108 (\% 79.4) kız ve 28 (\% 20.6) erkek olmak üzere toplam 136 öğrencisinden oluşmaktadır. Model olarak betimsel model benimsenen araştırmamızda veriler "Kişisel Bilgi Formu", "Özgüven Ölçeği" ve "İçsel Dini Yönelim Ölçeği” kullanılarak elde edilmiştir. SPSS programında tanımlayıcı istatistiklerden standart sapma, aritmetik ortalama ve frekans analizi; verilerin normal dağılım şartlarını tam olarak sağlayamaması üzerine non parametrik testlerden Man Whitney U Testi, Kruskal Wallis H Testi, Spearman korelasyon ve Post hoc analiz işlemleri anlamlılık $\quad \mathrm{p}<0.05$ kabul edilerek uygulanmış ve şu sonuçlara ulaşılmıştır:

1. Katılımcıların genel özgüven ve dindarlık düzeyleri yüksektir.

2. Özgüven ile dindarlık arasında anlamlı bir ilişki bulunamamıştır.

3. Kişisel dindarlık algısının, özgüven ve dindarlık üzerinde oluşturduğu fark istatistiksek açıdan anlamlıdır. 
4. Ekonomik durumu yüksek olanların özgüvenleri yüksektir ve oluşan fark istatisitiksel açıdan anlamlı bulunmuşur. Ancak ekonomik durumun dindarlık üzerinde oluşturduğu fark anlamlı bulunmamıştır.

5- Cinsiyet, memleketin bulunduğu coğrafi bölge, iletişim araçlarıyla günlük meşguliyet süresi, kişisel gelişime (kitap okuma, kurs, seminer vb. etkinlikler) günlük ayrılan süre, pandemi sürecinin günlük hayata olumsuz etkisine yönelik alg1, barınma yeri değişkenlerinin oluşturduğu fark istatistiksel açıdan anlamlı bulunmamıştır.

Araştırmamızda yüksek ekonomik ddurumun özgüven üzerine ve kişisel dindarlık algısının özgüven ile dindarlık üzerinde oluşturduğu anlamlı fark bağlamında şu önerilerde bulunulmuştur:

1. Dogmatik olmayan, sorgulayan bir zihinsel altyapı üzerine bilimsel yöntemlerle desteklenerek, kişinin duygu, düşünce, sosyal ve psikolojik yönlerinin gelişimine katkı sunacak bir müfredatla din eğitimi gerçekleştirilmelidir.

2. Dinin gülen yüzünü gösteren, insani ilişkileri önceleyen, radikallikten uzak, ötekileştirici değil birleştirici yapıda sağlıklı bir dindarlık anlayışının oluşumu için gerekli eğitimsel alt yapı hazırlanmalıdır.

3. Kendilik algılarının öğrencilerin psikososyal yapılarını etkileme potansiyeli dikkate alınarak, kendilik algısını geliştirici etkinliklere önem verilmelidir.

4. Öğrenciler barınma, giyim, ulaşım, eğitim materyalleri gibi eğitim süreçleriyle ilgiliher türlü gereksinimleri kapsayacak ölçüde ekonomik olarak desteklenmelidir.

\section{Kaynakça}

Acar, M. C. (2019). Öz Güven ile Dindarlık Arasındaki İlişki: Üniversite Öğrencileri Üzerine Bir Araştırma. Bingöl Üniversitesi Illahiyat Fakültesi Dergisi.14, 64-78. http://dx.doi.org/10.34085/buifd.611302

Acat, B.1 (2019). Ergenlerde Dindarlık, Değerler, Internet Bağımlılı̆ğ Ve Hayat Memnuniyeti İlişkisi. Marmara Üniversitesi / Sosyal Bilimler Enstitüsü. Yüksek Lisans Tezi.

Aka, M. (2019). İlkokul Öğrencilerinin Özgüveni Ve Empatik Eğilimi Arasındaki İlişkinin İncelenmesi. Çukurova Üniversitesi / Sosyal Bilimler Enstitüsü. Yüksek Lisans Tezi.

Akagündüz, N. (2006). Insan Yaşamında Özgüven Kavramı. Ümraniye Rehberlik ve Araştırma Merkezi Müdürlüğü Yayınları.

Akın, A. (2007). Öz Güven Ölçeği’nin Geliştirilmesi ve Psikometrik Özellikleri, Abant İzzet Baysal Üniversitesi Eğitim Fakültesi Dergisi, 7 (2), 165-175.

Akkuş, Z. (2015). Ergenlerde Psikolojik Dayanıklılı̆̆ın Özgüven Ve Anne Baba Tutumları İle İlişkisi. Dokuz Eylül Üniversitesi / Eğitim Bilimleri Enstitüsü. Yüksek Lisans Tezi.

Alphan, M. (2018). Dans Etkinliklerinin Öz-Yeterlik, Özgüven Ve Sosyal Beceriye Etkisi: İsitme Engelli Bireyler Üzerine Bir Çalı̧̧ma. Manisa Celal Bayar Üniversitesi / Sosyal Bilimler Enstitüsü. Yüksek Lisans Tezi

Altıntaş, E. (2015). Kuramdan Uygulamaya Özgüven. Nobel Akademik Yayıncılık.

Altuntaş, Y. (2019). Üniversitelerin Tenis Oynayan Beden Ĕ̆itimi Ve Spor Bölümü Öğrencilerinin Özgüven Düzeylerinin Yaşam Doyumu Ve Yaşam Kalitesine Etkisi. Marmara Üniversitesi / Sağlık Bilimleri Enstitüsü. Yüksek Lisans Tezi 
Aslan, Y.n (2016). Lise Son Sinıf Öğrencilerinin Affedicilik Özelliği İle Özgüven Düzeyleri Arasındaki İlişki. Nişantaşı Üniversitesi / Sosyal Bilimler Enstitüsü. Yüksek Lisans Tezi.

Atılgan, D. (2018). Spor Yönetiminde Görev Alan Yöneticilerde Kriz Yönetimi, Karar Verme Ve Özgüven Beceri Düzeyleri Arasındaki İlişkinin İncelenmesi. Selçuk Üniversitesi / Sağlık Bilimleri Enstitüsü. Doktora Tezi.

Aydemir, R. E. (2008). Dindarlık Ve Mutluluk İlişkisi (İlk Yetişkinlik Dönemi). Ondokuz Mayıs Üniversitesi / Sosyal Bilimler Enstitüsü. Yüksek Lisans Tezi.

Aydıner, B. B. (2011). Üniversite Öğrencilerinin Yaşam Amaçlarının Alt Boyutlarının Genel ÖzYeterlik, Yaşam Doyumu Ve Çeşitli Değişkenlere Göre İncelenmesi. Sakarya Üniversitesi, Eğitim Bilimleri Enstitüsü. Yüksek Lisans Tezi.

Ball, J., Armistead, L. \& Austin, B. - J. ( 2003). The Relationship Between Religiosity and Adjustment Among African-American Female, Urban Adolescents, Journal of Adolescence. 26(3), 431-446.

Bandura, A. (1997). Self-efficacy: The exercise of control, Freeman

Bilgin, O. (2017). Ergenlerin Özgüven Düzeyi ile Yaşam Amacı ve Diğerleriyle Olumlu İlişkiler Arasındaki İlişki. Yaşadıkça Eğitim, 31 (2), 55-66.

Bostancı, Ö., Karaduman , E. \& Şebin, K. (2018). Dağcıların Özgüven Seviyelerinin Çeşitli Değişkenler Açısından İncelenmesi. Beden Eğitimi ve Spor Bilimleri Dergisi. 20(3), 145154.

Bulut, M. B. (2017). Examining The Influence Of Psychological Well-Being, Religious Worldviews and Self-Confidence on Family Leadership Orientation. International PeerReviewed Journal of Humanities and Academic Science 20, 35-54.

Campos, J, J., Campos R.G. \& Barrett, K.C. (1989) . Emergent Themes İn The Study Of Emotional Development And Emotion Regulation. Developmental Psychology, 25, 394-402.

Cengil, M. (2003). Depresyonu Önlemede Dini İnancın Koruyucu Rolü, Dinbilimleri Akademik Araştırma Dergisi, 3(3), 129-152.

Çakır, B. (2015). Ortaokul Öğretmenlerinin Dindarlık Düzeyleri İle Empatik Eğilim Düzeylerinin Bazı Değişkenler Açısından İncelenmesi (Ünye Örneği). Ondokuz Mayıs Üniversitesi / Sosyal Bilimler Enstitüsü. Yüksek Lisans Tezi.

Çalıkuşu, H. (2020). Ergenlerde Özgüven İle Olumsuz Otomatik Düşünceler Arasındaki İlişkinin İncelenmesi. Selçuk Üniversitesi / Eğitim Bilimleri Enstitüsü. Yüksek Lisans Tezi.

Çalışır, M. (2014). Sporcularda Psikolojik Sağllk Ve Dindarlık İlişkisinin İncelenmesi. Muğla Sıtk1 Koçman Üniversitesi / Sağlık Bilimleri Enstitüsü. Yüsek Lisans Tezi.

Çetin, S. (2019). Elit Sporcuların Duygusal Zeka, Öz-Yeterlik Ve Öz Güven Düzeyleri Arasındaki İlişkinin İncelenmesi. Çanakkale Onsekiz Mart Üniversitesi / Sağlık Bilimleri Enstitüsü. Yüksek Lisans Tezi.

Demir, Ö., Acar, M. (1997). Sosyal Bilimler Sözlüğ̈̈. Vadi Yayınları.

Doğru, Z. (2017). Beden Eğitimi ve Spor Eğitimi Öğrencilerinin Özgüven ve Özyeterlik Algıları Arasındaki İlişkinin Değerlendirilmesi. Beden Eğitimi ve Spor Araştırmaları Dergisi 9(1), 13- 23.

Dursun, E. (2018). Çocukluk Çağında Aile İçerisinde Şiddete Maruz Kalmış Bireylerde Özgüven Ve Öfke Kontrol Durumlarının İncelenmesi. İstanbul Gelişim Üniversitesi / Sosyal Bilimler Enstitüsü. Yüksek Lisans Tezi. 
Ekmekçi, S. (2016). Benlik Saygısı Ve Dindarlık İlişkisi: Denizli Örneği.Süleyman Demirel Üniversitesi / Sosyal Bilimler Enstitüsü. Yüksek Lisans Tezi.

Eldeleklioğlu, J. (2004). Çocuklarda Özgüven Gelişimi. Gazi Üniversitesi Eğitim Fakültesi Dergisi, 24 (2), 111-121.

Elsel, D. (2019). Yetişkin Bireylerin Özgüvenleri İle Psikolojik Sağlamlık Düzeyleri Arasındaki İlişki. Ondokuz Mayıs Üniversitesi / Eğitim Bilimleri Enstitüsü. Yüksek Lisans Tezi.

Erden, N. (2019). Lise Öğrencilerinin Özgüven Düzeyinin İnternet Bağımlılığına Etkisi Üzerine Bir Araştırma. Marmara Üniversitesi / Eğitim Bilimleri Enstitüsü. Yüksek Lisans Tezi.

Erpalabıyık, B. (2018). Üniversite Öğrencilerinin Gençlik Liderlik Özellikleri İle Benlik Saygısı Ve Özgüven Algiları Arasındaki İlişkilerin İncelenmesi. Siirt Üniversitesi / Sosyal Bilimler Enstitüsü. Yüksek Lisans Tezi.

Esati, A. (2017). Ergenlerin Özgüven Oluşturmalarında Dindarlı̆̆ın Rolü (Sancak Örneği). Uludağ Üniversitesi Sosyal Bilimler Enstitüsü. Yüksek Lisans Tezi.

Esentaş, M., Işıkgöz, E., Karacan Doğan, P. \& Şahin, M. H. (2017).Gençlik Kampı Kadın Lider Adaylarının Özgüven Düzeyleri. Kastamonu Ĕ̈itim Dergisi 5(1), 315-328.

Geçioğlu, A. R. (2018). Evlilik uyumu-dindarlık ilişkisi: Adana örneği. Çukurova Üniversitesi / Sosyal Bilimler Enstitüsü. Doktora Tezi.

Gencer, N. (2019a). Hemodiyaliz Hastalarında Dindarlık Ve Öznel İyi Oluş. Hitit Üniversitesi / Sosyal Bilimler Enstitüsü. Doktora tezi.

Gencer, N. (2019b). İmam Hatip Lisesi Öğrencilerinin Özgüven Düzeyleri Hakkında Nicel Bir Analiz. Bilimname, 2019(4), 407-440 .

George, D., Mallery, P.. (2010). SPSS For Windows Step By Step: A Simple Guide And Reference 17.0 Update (10th Edition). Pearson.

Gezenler, A. (2019). Orta Yetişkinlik Dönemi Dindarlık Ve Mutluluk İlişkisi. Ondokuz Mayıs Üniversitesi / Sosyal Bilimler Enstitüsü. Yüksek Lisans Tezi.

Günay, Ü. (2006). Dindarlı̆̆ın Sosyolojisi. Dindarlı̆̆ın Sosyo-Psikolojisi. ed. Ünver GünayCelaleddin Çelik. Karahan Kitabevi. 1-59.

Gündoğdu, H. (2019). Okul Spor Takımlarında Olan Ve Olmayan 12-14 Yaş Arası Kız Çocuklarının Özgüven Ve Benlik Saygısı Değerlerinin İncelenmesi. Maltepe Üniversitesi / Sosyal Bilimler Enstitüsü. Yüksek Lisans Tezi.

Gürler, İ. (2015). Correlation Between Selfconfidence And Speaking Skill Of English Language Teaching And English Language And Literature Preparatory Students, Curr Res Soc Sci., $1(2), 14-19$.

Hoge, R. (1972). A Validated İntrinsic Religious Motivation Scale. Journal for the Scientific Study of Religion, 11(4), 369-376.

İnan, T. (2019). Üniversite Öğrencilerinin Dindarlık Düzeylerinin Hayatı Anlamlandırmada Etkisi (Ăgrı İbrahim Çeçen Üniversitesi Örneği). Atatürk Üniversitesi / Eğitim Bilimleri Enstitüsü. Yüksek Lisans Tezi.

İnce, N. (2019). Dindarlık Ve Psikolojik Dayanıklılık Illişkisi: Burdur Örneği. Süleyman Demirel Üniversitesi / Sosyal Bilimler Enstitüsü. Yüksek Lisans Tezi.

Karaca, F. (2000). Ölüm Psikolojisi. Beyan Yayınları. 
Karaca, F. (2001). Din Psikolojisinde Metot Sorunu Ve Bir Dindarlık Ölçeğinin Türk Toplumuna Standardizasyonu. EKEV Akademi Dergisi, 3(1), 187-201.

Karademir, N. (2015).Fen Edebiyat Fakültesi Coğrafya Bölümü Öğrencilerinin Özgüven Algıları. KSÜ Sosyal Bilimler Dergisi, 12(1), 53-77.

Karasar, N.(2009). Bilimsel araştırma yöntemi. Nobel Yayıncılık.

Kasatura, İ. (1998). Kişilik ve Özgüven. Evrim Yayınevi.

Kırman, F. (2013). Stres Ve Din: Lise Gençliği Üzerine Psikolojik Bir Araştırma (Kahramanmaraş Örneği). Kahramanmaraş Sütçü İmam Üniversitesi / Sosyal Bilimler Enstitüsü. Yüksek Lisans Tezi.

Koç, S., Gün, N. (2007). Özsaygı: Öncelikler Listende Kaçıncı Sıradasın? (3.Baskı). Kuraldış1 Yayıncilik.

Lauster, P. (2000). Kendine Güven, Doruk Yayınları.

Mandıralı, S. (2019). Farkındalık Temelli Yaratıcı Drama Programının Sporcuların Psikolojik Dayanıklılık, Özgüven Ve Stresle Başa Çıkma Stratejileri Üzerine Etkisi-Genç Basketbolcular Örneği. Marmara Üniversitesi / Sağlık Bilimleri Enstitüsü . Yüksek Lisans Tezi

Mckay, M., Fanning, P. (2016). Özgüven, Çev. Fatoş Gaye Atay, Arkadaş Yayınevi.

Merey, B. (2010). Yetişkinlerde Özgüven Duygusu İle Anksiyete Düzeyi Arasındaki İlişkinin Karşılaştırılması Ve Kültürlerarası Bir Yaklaşım. Maltepe Üniversitesi / Sosyal Bilimler Enstitüsü. Yüksek Lisans Tezi.

Noyan Yalman, İ., Özkaynar, K. (2018). Öğrencilerin Özgüven Seviyeleri İle Mesleki Başarı Düzeyleri Arasındaki İlişki: Cumhuriyet Üniversitesi Meslek Yüksekokullarında Uygulama. C. Ü. İktisadi ve İdari Bilimler Dergisi, 19(1),223-233.

Özdamar, K. (2002). Paket Programları İle İstatistiksel Veri Analizi- 2 (Çok Değĭşkenli Analizler), Kaan Kitapevi.

Parçal, K. F. (2018). Ergenlerin Sosyal Anksiyete Düzeyleri İle Özgüven Alglları Arasındaki İlişkinin Incelenmesi. Haliç Üniversitesi / Sosyal Bilimler Enstitüsü .Yüksek Lisans Tez.

Sarıçam, H., Güven, M. (2012). Özgüven Ve Dini Tutum. The Journal of Academic Social Science Studies. 5(7),573-586.

Yılmaz Sarkın, S. (2012). Çocuğa Yönelik Aile İçi Şiddetin İlköğretim 6. 7. Ve 8. Sinıf Düzeyindeki Öğrencilerin Iletişim Becerileri Ve Özgüven Düzeylerine Etkisi. Necmettin Erbakan Üniversitesi / Eğitim Bilimleri Enstitüsü. Yüksek Lisans Tezi.

Sezgin, K. (2016). Üniversite Öğrencilerinin Psikolojik Sağlamlık Ve Dindarlık Düzeylerinin Incelenmesi (Dicle Üniversitesi Örneği). Dicle Üniversitesi / Sosyal Bilimler Enstitüsü. Yüksek Lisans Tezi.

Soner, O. (1995). Aile Uyumu, Öğrenci Özgüveni Ve Akademik Başarı Arasındaki İlişkiler. Marmara Üniversitesi / Sosyal Bilimler Enstitüsü. Doktora Tezi.

Soykan, Ö., Mirzeoğlu, A. D. (2020). Halk Oyunlarının Üniversite Öğrencilerinin Sosyal Beceri Ve Özgüven Düzeylerine Etkisi. SPORMETRE Beden Eğitimi ve Spor Bilimleri Dergisi. 18(2), 136 - 156.

Şahin, A. (2005). Ergenlerde Dindarlık-Benlik Saygısı İlişkisi, Selçuk Üniversitesi İlahiyat Fakültesi Dergisi, 19: 187-197. 
Şahin, A. (2008). Ergenlerde Dindarlık ve Empati, Marife: Dini Araştırmalar Dergisi, 8(1), 149166

Şeftalici, B. (2017). Lise Son Sinıf Öğrencilerinde Sinav Kaygısı Ve Maneviyat ŞanlıurfaViranşehir Örneği.Çukurova Üniversitesi / Sosyal Bilimler Enstitüsü. Yüksek Lisans Tezi.

Şengül, F. (2007). Dindarlık Ve Ruh Să̆glı̆ İlişkisi.Marmara Üniversitesi / Sosyal Bilimler Enstitüsü. Yüksek Lisans Tezi.

Toktaş, S. (2017). Okul Spor Müsabakalarına Katılan Lise Öğrencilerinin Kaygı, Özgüven Ve Güdülenmeleri Arasındaki İlişkilerin İncelenmesi. Karadeniz Teknik Üniversitesi / Eğitim Bilimleri Enstitüsü. Yüksek Lisans Tezi.

Tokur, B. (2011). Stres-Dindarlı İlşkisi Üzerine Bir Araştırma. Atatürk Üniversitesi / Sosyal Bilimler Enstitüsü. Doktora Tezi.

Tokur, B. (2014). Dindarlık Sorunu: Psikolojik Bir Tahlil. Atatük Üniversitesi Illahiyat Fakültesi Dergisi, 41,257-279.

Tura, H. (2019). Dindarlık, Affetme Ve Psikolojik Iyi Oluş İlişkisi . Marmara Üniversitesi / Sosyal Bilimler Enstitüsü.Yüksek Lisans Tezi.

Türker, N. Y. (2018). Yetişkinlerde Dindarlı Ve Psikolojik Sağlamlık İlişkisi Üzerine Bir Araştırma. Uludağ Üniversitesi / Sosyal Bilimler Enstitüsü. Yüksek Lisans Tezi.

Ünverdi, M. S. (2020). Din Görevlilerinde Öz-Güven: Mardin İli Örneği . Mardin Artuklu Üniversitesi Sosyal Bilimler Enstitüsü. Yüksek Lisans Tezi.

WHO (2020). https://www.who.int/dg/speeches/detail/who-director-general-s-opening-remarks-atthemedia-briefing-on-COVID-19---11-march-2020. doi:10.1007/s12603-017-0883-6, Erişim Tarihi: 23.04.2020.

Yakut, S. (2019). Üniversite Öğrencilerinde Öz-Denetim. Uluslararası Sosyal Araşttrmalar Dergisi. 12(65),1409-1418. 581. http://dx.doi.org/10.17719/jisr.2019.3549.

Yazıc1, V. (2018). Camide İbadet Edenlerde Dindarlık, Yaşam Doyumu Ve Kimlik Yönelimleri, Nişantaşı Üniversitesi / Sosyal Bilimler Enstitüsü . Yüksek Lisans Tezi. 